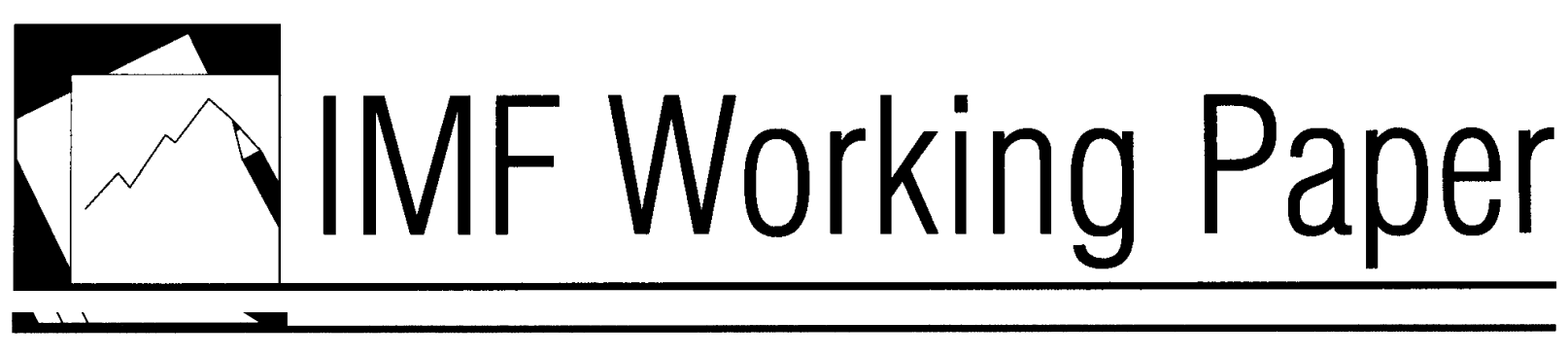

\title{
Accounting Discretion of Banks During a Financial Crisis
}

\author{
Harry Huizinga and Luc Laeven
}




\title{
IMF Working Paper
}

\author{
Research Department
}

\section{Accounting discretion of banks during a financial crisis}

\author{
Prepared by Harry Huizinga and Luc Laeven ${ }^{1}$
}

Authorized for distribution by Stijn Claessens

September 2009

\section{Abstract}

\section{This Working Paper should not be reported as representing the views of the IMF.}

The views expressed in this Working Paper are those of the author(s) and do not necessarily represent those of the IMF or IMF policy. Working Papers describe research in progress by the author(s) and are published to elicit comments and to further debate.

This paper shows that banks use accounting discretion to overstate the value of distressed assets. Banks' balance sheets overvalue real estate-related assets compared to the market value of these assets, especially during the U.S. mortgage crisis. Share prices of banks with large exposure to mortgage-backed securities also react favorably to recent changes in accounting rules that relax fair-value accounting, and these banks provision less for bad loans. Furthermore, distressed banks use discretion in the classification of mortgage-backed securities to inflate their books. Our results indicate that banks' balance sheets offer a distorted view of the financial health of the banks.

JEL Classification Numbers: A10; A11

Keywords: Key bank regulation, accounting standards, fair value accounting, corporate disclosure, financial crisis

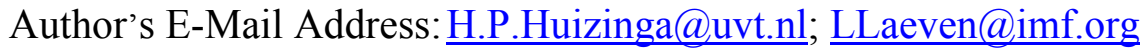

\footnotetext{
${ }^{1}$ Huizinga is Professor of Economics at Center, Tilburg University, and Research Fellow at CEPR; Laeven is Senior Economist at the International Monetary Fund, and Research Fellow at CEPR. We would like to thank Rocco Huang, Christian Leuz, Joe Mason, Lev Ratnovski, and Wolf Wagner for comments or suggestions, and Mattia Landoni for excellent research assistance. The findings, interpretations, and conclusions expressed in this paper are entirely those of the authors. They should not be attributed to the IMF. Contact information: Harry Huizinga: H.P.Huizinga@uvt.nl; Luc Laeven: 1laeven@,imf.org.
} 
I. Introduction 3

II. Tobin's $q$ Value and Market Discounts...................................................................

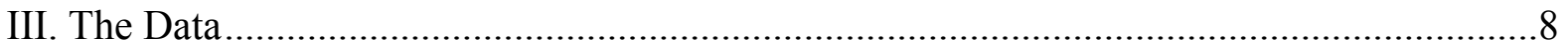

IV. Market Discounts and Valuation Effects of Real Estate Related Assets.........................12

A. Empirical Evidence on Market Discounts ...........................................................12

B. Banks' Stock Price Reaction to Amendments of Fair Value Accounting Rules ....16

V. Accounting Discretion on Impaired Assets and Asset Classification.............................18

A. Accounting Discretion on Accounting for Bad Loans ..........................................18

B. Classification of Mortgage-Backed Securities...................................................20

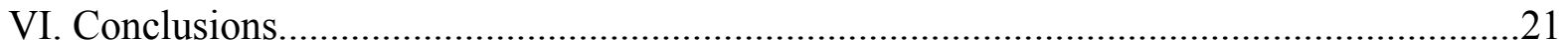

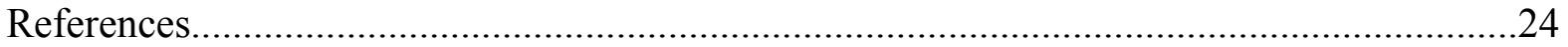

Appendix

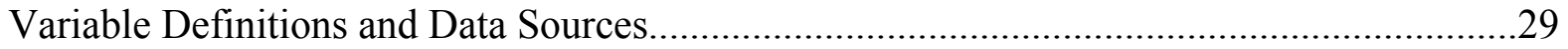

Tables

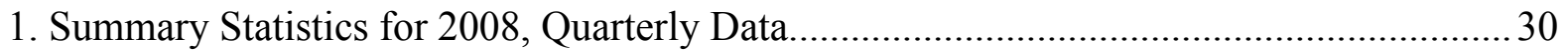

2. Tobin's q and Real Estate Related Assets in 2008 ......................................................31

3. Tobin's q and Real Estate Related Assets in 2001-2007...................................................32

4. Tobin's q Real Estate Related Assets and Asset Size........................................................33

5. Tobin's q and Additional Balance Sheet and Off-balance Sheet Items .............................34

6. Event Study of New FASB Rules on Fair Value Accounting for Illiquid Assets (FAS 157), Announced on October 10, 2008.....................................35

7. Event Study of FASB Amendments to Fair Value Accounting of

Hard-to-Value Assets, Announced on April 9, 2009....................................................36

8. Loan Loss Provisions and Net Loan Charge-offs in 2008 ...............................................37

9. Share of Mortgage-backed Securities that is Held-to-Maturity in 2008..............................38

10. Share of Non-Guaranteed Mortgage-backed Securities that is Held-to-Maturity in 2001-2007.

Figures

1. Tobin's q and Share of Zombie Banks......................................................................40

2. Real Estate Loans and Mortgage-backed Securities..................................................40

3. Share of Mortgage-backed Securities that is Held-to-Maturity........................................40

4. Fair Value of Mortgage-backed Securities Relative to Amortized Cost............................41

5. Tier 1 Capital Ratio and Share of Tier 1 Capital in Total Capital......................................41 


\section{INTRODUCTION}

The current financial crisis has reinvigorated a debate on the effectiveness of the existing accounting and regulatory frameworks for banks. Questions abound, ranging from adequate capitalization levels of banks to the boundaries of financial regulation (see Financial Stability Forum, 2008). Part of the debate on financial reform centers around required information on banks for effective market discipline and supervisory action. This includes not only thinking on the required level of detail on disclosure of bank assets and liabilities but also on their valuation techniques and the appropriateness of current accounting rules more generally (see Laux and Leuz, 2009, for a survey).

Part of this debate centers around the pros and cons of fair value accounting, where fair value is meant to indicate the price at which an asset could be bought or sold in a current transaction between willing parties, other than in a liquidation. Accounting standards stipulate that as a guiding principle, the quoted market price in an active market should be used as the basis for the measurement of the fair value of an asset. The problem is that such a price is not always available, for example, in illiquid markets. In such cases, fair values need to be estimated based on available information. A related concern is the potential procyclical nature of fair value accounting, which could magnify fluctuations in bank lending and economic activity (see IMF, 2009, and Heaton et al., 2009). A broader concern is that the current "mixed attribute" model of accounting, in which some financial instruments are measured based on historical cost and some at fair value, together with discretion over how financial instruments are measured, gives rise to accounting arbitrage. ${ }^{2}$

Despite difficulties of determining fair values in illiquid markets, advocates of fair value accounting maintain that fair value is the most relevant measure for financial instruments. ${ }^{3}$ They argue that financial assets, even complex instruments, tend to trade continuously in markets and it should therefore be possible to use information embedded in market prices to compute fair values of financial assets.

Faced with massive write-downs and expected losses, banks in contrast have used the momentum to lobby against the use of fair value accounting. They claim that most of their assets are currently not impaired, that they intend to hold them to maturity anyway, and that market prices reflect distressed sales into an illiquid market. Potential buyers of such assets, however, are unlikely to value them at origination value but at prices well below book value. Banks may ignore such signals to avoid recognizing a loss, claiming that unusual market conditions, not an actual decline in value, cause low market pricing.

\footnotetext{
${ }^{2}$ As emphasized by Jackson M. Day, Deputy Chief Accountant, U.S. Securities and Exchange Commission, in his year 2000 remarks "Fair Value Accounting-Let's Work Together and Get It Done!" at the 28th Annual National Conference on Current SEC Developments.

${ }^{3}$ See, for example, Kaplan, Robert, Robert Merton and Scott Richard, 2009, "Disclose the fair value of complex securities", Financial Times, August 17, 2009.
} 
Accounting techniques do not generally generate large differences between the book and market value of bank assets. At times of financial crisis when asset markets become distressed, however, large differences between book and market values of assets may arise, especially when assets are carried at values based on historical cost. Such differences may give rise to incentives for banks to use accounting discretion to preserve the book value of the bank, for example, by using advantageous asset classifications or valuation techniques. As a consequence, discretion in accounting rules enables banks to understate underlying balance sheet stresses. Overstated book values of bank assets may further give rise to undue regulatory forbearance. ${ }^{4}$

During the ongoing financial crisis, large differences have indeed arisen between market and book values of U.S. banks as their market values have sharply eroded on the expectation of major writedowns and losses on real estate related assets. By end-2008, more than $60 \%$ of U.S. bank holding companies had a market-to-book value of assets of less than one, compared to only $8 \%$ of banks at end-2001. At the same time, the average ratio of Tier 1 capital to bank assets has stayed constant at about $11 \%$ throughout this period. The market value of bank equity thus has dropped precipitously against a backdrop of virtually constant book capital. This raises doubts about the relevance and reliability of banks' accounting information, the two main criteria on the basis of which accounting systems are evaluated, at a time of financial crisis.

This paper shows that banks use accounting discretion to systematically understate the impairment of their real estate related assets, especially following the onset of the current financial crisis, in an effort to preserve book capital. We provide the first evaluation of such behavior and offer three pieces of compelling evidence to support our thesis that banks use accounting discretion to overstate the book value of capital.

First, we estimate large market discounts on real estate related assets, including mortgage loans and mortgage-backed securities (MBS). To estimate implicit market discounts on bank assets, we empirically relate Tobin's $q$, computed as the market-to-book value of assets, to banks' asset exposures using quarterly accounting data on U.S. bank holding companies for the period 2001 to 2008. Our primary focus is on real estate related assets, as these assets constitute a large fraction of the total assets of the average bank, and as recent declines in U.S. real estate prices have raised doubts about the underlying value of these assets. However, we also apply our methodology to other on- and off-balance sheet items. We estimate significant discounts on banks' real estate loans (relative to other loans) starting in 2005, averaging about $10 \%$ in 2008. As the average bank holding company in 2008 holds about $54 \%$ of its assets in the form of real estate loans, the implicit discount in loan values goes a long way toward explaining the current depressed state of bank share prices. We further find that investors started discounting banks' holdings of MBS in 2008. For that year, we find an average discount on these assets of $24 \%$ (relative to other securities), while the average MBS exposure amounted to $10 \%$ of assets. The market discount on MBS that are available-for-sale (and carried at fair value) is estimated to be $23 \%$, against a discount of $32 \%$ for MBS that are held-to-maturity (and carried at values based

\footnotetext{
${ }^{4}$ For evidence of regulatory forbearance and the political economy of bank intervention, see Kane (1989), Kroszner and Strahan (1996), Barth et al. (2006), and Brown and Dinc (2005, 2009).
} 
on historical cost). Thus, even MBS that are carried at fair value appear to be overvalued on the balance sheets of banks.

Second, using an event study methodology we find that banks with large exposure to MBS experienced relatively large excess returns when rules regarding fair value accounting were relaxed. Pressures arose during the summer of 2008 to provide banks with more leniency to determine the fair value of illiquid assets such as thinly traded MBS to prevent these fair values from reflecting 'fire sale' prices. ${ }^{5}$ Correspondingly, on October 10, 2008 the Financial Accounting Standards Board (FASB) clarified the allowable use of non-market information for determining the fair value of financial assets when the market for that asset is not active.

Subsequently, on April 9, 2009, the FASB announced a related decision to provide banks greater discretion in the use of non-market information in determining the fair value of hard-to-value assets. As expected, the stock market on both occasions cheered the banks' enhanced ability to maintain accounting solvency in an environment of low transaction prices for MBS. Using an event study methodology, we find that banks with large exposure to MBS experienced relatively large excess returns around both announcement dates, indicating that these banks in particular are expected to benefit from the expanded accounting discretion.

Third, we show that banks use accounting discretion regarding the realization of loan losses and the classification of assets to preserve book capital. Banks have considerable discretion in the timing of their loan loss provisioning for bad loans and in the realization of loan losses in the form of charge-offs. Thus, banks with large exposure to MBS and related losses can attempt to compensate by reducing the provisioning for bad debt in an effort to preserve book capital. We indeed find that banks with large portfolios of MBS report relatively low rates of loan loss provisioning and loan charge-offs.

We also examine banks' choices regarding the classification of MBS as either held-tomaturity or available-for-sale. We consider this categorization separately for MBS that are covered or issued by a government agency. In 2008, the fair value of especially non-guaranteed MBS tended to be less than their amortized cost. This implies that banks could augment the book value of assets by classifying MBS as held-to-maturity. Indeed, we show that the share of nonguaranteed MBS that are held-to-maturity increased substantially in 2008. Classification of this kind is particularly advantageous for banks whose share price is depressed on account of large real estate related exposures. Consistent with this, we find that the share of MBS kept as held-tomaturity is significantly related to both real estate loan and MBS exposures. Moreover, these relationships are stronger for low-valuation banks.

Taken together, the evidence of this paper shows that banks use considerable accounting discretion regarding the categorization of assets, valuation techniques, and the treatment of loan losses. Accounting discretion appears to be used to soften the impact of the crisis on the book

\footnotetext{
${ }^{5}$ The primary concern was one of maintaining solvency at affected banks. There was also a concern that losses induced by fire sales could spread to other financial institutions. Allen and Carletti (2008) and Plantin et al. (2008) offer theoretical models investigating potential contagion effects among banks if fair value accounting forces banks to value their securities according to observed 'fire sale' prices.
} 
valuation of assets. While some accounting discretion is unavoidable as accounting systems in part are mechanisms for firms to reveal asymmetric information to investors and other outside parties $^{6}$, accounting discretion entails the risk of generating highly inaccurate accounting information at a time of great turmoil, such as the present financial crisis. Inaccurate accounting information in the case of banks can be especially harmful, as it may lead to regulatory forbearance with concomitant risks for tax payers. In the present crisis, the financial statements of banks appear to overstate the book value of assets to the point of becoming misleading guides to investors and regulators alike. ${ }^{7}$ Thus, the present crisis can be seen as a 'stress test' of the accounting framework that reveals that book valuation need not always reflect the best estimate of asset value, especially at a time of sharp declines in market values. Accounting reforms announced so far and discussed in this paper, however, seem to go in the direction of increasing the gap between book and market values. This may be testimony that bank interests weigh heavily in this debate.

Our paper relates to a large literature in accounting and finance on how accounting principles and systems affect corporate behavior and that of banks in particular (see, e.g., Collins et al., 1995, Shackelford et al., 2008, and Leuz and Wysocki, 2008). Much of this work analyzes the cost and benefits of earnings management of firms (see, e.g., Leuz et al., 2003, and Hutton et al., 2008). There is also work on the costs and benefits of enhanced corporate disclosure and accounting transparency (see Leuz and Wysocki, 2008, for a review). For example, Karpoff et al. (2008) using firm-level information on legal enforcement actions show that financial misrepresentation has reputational consequences for firms and depresses firm valuation.

A related literature reviewed by Barth et al. (2001) and Holthausen and Watts (2001) asks whether accounting information is value relevant in the sense that it conforms to the information that bank shareholders use to price bank shares. Barth et al. (1996) and Eccher et al. (1996) find that fair value estimates of loan portfolios and securities help to explain bank share prices beyond amortized cost. There is also recent work on the market pricing of bank assets reported under different fair valuation techniques (e.g., Kolev, 2009, Goh et al., 2009, and Song et al., 2009). Bongini et al. (2002) further find that measures of bank fragility based on market information are a better predictor of bank failures than measures of bank fragility based on accounting information.

Our paper is part of an emerging literature on the causes and effects of the 2007 U.S. financial crisis. This work shows that house price appreciation (e.g., Demyanyk and Van Hemert, 2008) and asset securitization (e.g., Keys et al., 2008; Mian and Sufi, 2008; Loutskina and Strahan, 2009), combined with a more general deterioration of lending standards by banks (e.g.,

\footnotetext{
${ }^{6}$ A theoretical literature outlines that managers of firms may have incentives to smooth reported accounting incomes either to smooth their own compensation, to increase their job security, or to increase firm valuation by investors (see, e.g., Trueman and Titman, 1988, Fudenberg and Tirole, 1995, and Sankar and Subramanyam, 2000).

${ }^{7}$ The outcomes of stress tests of major U.S. banks conducted by the U.S. Treasury in 2009, which calculated capital shortfalls at several major banks, are testimony to the fact that publicly available accounting information at the time provided an inadequate picture of the health of the concerned banks.
} 
Dell'Ariccia et al., 2008), helped fuel a crisis in U.S. mortgage markets, with bank capital being eroded as the asset price bubble in real estate markets burst starting in 2007.

The paper continues as follows. Section II sets out the relationship between Tobin's $q$ and market discounts on bank assets. Section 3 discusses the data. Section IV first presents empirical evidence on market discounts of real estate related assets relative to book values. Subsequently, it provides evidence on the stock market response to the announcements of more lenient rules for accounting for illiquid assets. Section V examines the use of bank discretion regarding loan loss provisioning, loan charge-offs, and the classification of MBS into different accounting categories. Section VI concludes.

\section{TOBIN'S $Q$ VALUE AND MARKET DISCOUNTS}

In this section, we describe how observations of Tobin's $q$ can be used to infer discounts on bank assets implicit in the stock market. ${ }^{8}$ Let $M V$ be the market value of the bank. At the same time, let $A_{i}$ be the accounting value of asset $i$ and let $L_{i}$ be the accounting value of liability $i$. Assuming there are operating markets for a bank's assets and liabilities, we can state a bank's market value as follows:

$$
M V=\sum_{i} v_{i}^{a} A_{i}-\sum_{i} v_{i}^{l} L_{i}
$$

where $v_{i}^{a}$ is the market value of asset $i$ and $v_{i}^{l}$ is the market value of liability $i .^{9}$

We can define $q$ as the market value of the equity of the bank plus the book value of all liabilities divided by the book value of all assets as follows:

$$
q=\frac{M V+\sum_{i} L_{i}}{\sum_{i} A_{i}}
$$

Substituting for $M V$ from (1) into the expression for $q$, we get:

\footnotetext{
${ }^{8}$ In similar fashion, Sachs and Huizinga (1987) estimate discounts on third world debt on the books of U.S. commercial banks at the time of the international debt crisis of the 1980s. A related literature, starting with Lang and Stulz (1994) and including Laeven and Levine (2007), has studied discounts in Tobin's $q$ arising from corporate diversification. In that literature, discounts are computed for each business unit of a conglomerate with respect to the value of comparable stand-alone firms, while here we compute discounts for different assets and liabilities of the same bank.

${ }^{9}$ In eq. (1), we ignore that market value may depend on the co-existence of certain assets and liabilities as discussed in, for instance, DeYoung and Yom (2008).
} 


$$
q=1-\sum_{i} d_{i}^{a} a_{i}+\sum_{i} d_{i}^{l} l_{i}
$$

where $d_{i}^{a}=1-v_{i}^{a}, d_{i}^{l}=1-v_{i}^{l}, a_{i}=\frac{A_{i}}{\sum_{i} A_{i}}$ and $l_{i}=\frac{L_{i}}{\sum_{i} A_{i}}$. Note that $d_{i}^{a}$ and $d_{i}^{l}$ are the discounts implicit in the bank's stock price of a bank's assets and liabilities relative to book values. At the same time, $a_{i}$ and $l_{i}$ are the accounting values of particular assets and liabilities relative to the book value of all assets.

From eq. (2), we see that if all assets and liabilities of the bank are valued at market value in the bank's balance sheet, then $q$ equals 1 . Alternatively, a deviation of $q$ from 1 implies that the market valuation of at least one balance sheet items differs from its accounting value. ${ }^{10}$

\section{THE DATA}

In this study, we consider U.S. bank holding companies that are stock exchange listed. These companies report a range of accounting data to the Federal Reserve System by way of the Report on condition and income (Call report). We are using quarterly data from these Call reports from the final quarter of 2001 till the end of 2008. This covers a full business cycle as defined by the National Bureau of Economic Research (NBER) from the previous recession which ended in November 2001 until the current ongoing recession which started in December 2007. Our focus is on the year 2008, one year into the recession and what is generally considered the start of the U.S. mortgage default crisis (see for example Dell'Ariccia et al., 2008, and Mian and Sufi, 2008), when delinquencies on mortgage loans increased sharply.

Using stock market data from Datastream, we use the market value of common equity plus the book value of preferred equity and liabilities as a proxy for the market value of a bank's assets. Tobin's $q$ is then constructed as the ratio of this proxy for the market value of bank assets and the book value of assets. Figure 1 reports the average Tobin's $q$ per quarter over our sample period. The mean value of $q$ has declined from 1.064 in the final quarter of 2001 to 0.998 in the final quarter of 2008. This suggests that over this period, the market value of bank assets has declined more than its book value.

We define a zombie bank as a bank with a $q$ of less than one. ${ }^{11}$ The decline of the average $q$ has been accompanied by an increase of the share of banks that are zombie banks. As presented

\footnotetext{
${ }^{10}$ Current book values of, say, real estate loans could already reflect some loan loss provisioning. Estimated discounts on bank assets then reflect the difference between market perception of asset impairment and the recognition of this impairment through reported loan loss provisioning (rather than the difference between market value and origination value). Put differently, the estimated discount reflects the difference between market perception of any asset impairment and the accounting treatment of this impairment.

${ }^{11}$ The term zombie bank has frequently been used in the context of Japan during the 1990's banking crisis when Japanese banks continued to lend to unprofitable borrowers (e.g., Caballero et al., 2008).
} 
in Figure 1, the share of zombie banks has increased from 8.2\% at the end of 2001 to $60.4 \%$ at the end of 2008. During this period, the share of zombie banks has tended to be smaller than in 2001 and 2008 reflecting an upswing of the business cycle. In fact, the share of zombie banks reached a low of $0.3 \%$ during the second quarter of 2004 .

U.S. banks are exposed to the real estate market in two important ways. First, they have significant portfolios of real estate loans. As an index of this exposure, we construct the ratio of real estate loans to overall assets. From 2001 to 2008 this share of real estate loans has increased substantially from $45.2 \%$ to $53.3 \%$ for the average bank holding company as reflected in Figure 2. Thus, about half of the average bank's assets consist of real estate loans by 2008. In addition, banks are exposed to the real estate market through their holdings of MBS. Interestingly, the average ratio of the book value of MBS to the book value of all assets has increased only slightly from $10.0 \%$ in 2001 to $10.2 \%$ at the end of 2008 .

While there has been a move towards fair value accounting of bank assets, most assets of the average bank, including mortgage loans held for investment, are still reported based on historical cost. ${ }^{12}$ The book value of MBS reflects different accounting conventions depending on whether these securities are held-to-maturity or available-for-sale. MBS classified as held-tomaturity are carried at amortized cost. This amortized cost may be adjusted periodically for capitalized interest and may also reflect previous loan loss provisioning. However, these adjustments to amortized cost are likely to be relatively small so that amortized cost is relatively close to origination values. Alternatively, MBS can be available-for-sale. In this case, these securities are to be carried at fair value.

Fair value is meant to reflect observed market values (of either the underlying asset level 1 assets - or a comparable asset - level 2 assets) or otherwise reflect the outcome of a bank's own valuation models (level 3 assets). ${ }^{13}$ Again, banks' assessments of fair value may differ across banking institutions as the determination of fair value in practice leaves banks with significant discretion. ${ }^{14}$ At any rate, at a time of declining asset values, one expects fair values to be less than amortized cost.

\footnotetext{
12 The majority of (real estate) loans are carried at historical cost, as loans held for sale, that are reported at the lower of historical cost and fair value, constitute only a small fraction of less than $1 \%$ of total assets for the average bank.

${ }^{13}$ A breakdown of fair value assets by valuation technique (level 1 to 3 ) is in principle available from Schedule HC$\mathrm{Q}$ of the Call report. We do not use this information in our analysis, because, unlike securities that are reported at both amortized cost and fair value, these assets are reported for only one of the three fair valuation techniques, making it difficult to draw any inference based on a direct comparison of the amount of assets reported in each category. Furthermore, the level 1 to 3 assets are not broken down separately for real-estate related assets, which are the primary focus of our study, and are reported only for a subset of banks that have elected to report such assets under a fair value option. Moreover, the majority of these assets are valued as level 2 assets (about 90 percent of fair value assets in 2008), so there is not much variation in fair valuation technique.

${ }^{14}$ Indeed, work by Kolev (2009), Goh et al. (2009), and Song et al. (2009) shows that market discounts differ for level 1, level 2, and level 3 assets.
} 
Interestingly, banks report in their Call report filings both the amortized cost and fair value of MBS regardless of whether these are held-to-maturity or available-for-sale. Thus, for MBS that are carried at amortized cost we also know the assessed fair value, while for MBS carried at fair value we also know the reported amortized cost. This enables us to compute a bank's share of MBS that are held-to-maturity (rather than available-for-sale) on a single accounting basis. Specifically, we can compute the share of MBS that is held-to-maturity using amortized costs for all MBS.

The share of MBS that is held-to-maturity is computed separately for MBS that do and do not benefit from some explicit or implicit official guarantee. Guaranteed MBS are those that are guaranteed or issued by U.S. government agencies such as the Federal National Mortgage Association (FNMA), the Federal Home Loan Mortgage Corporation (FHLMC), and the Government National Mortgage Association (GNMA), more generally known as Fannie Mae, Freddie Mac, and Ginnie Mae, respectively. ${ }^{15}$ Figure 3 shows that for most of the sample period the share of non-guaranteed MBS classified as held-to-maturity exceeded the analogous share of guaranteed securities. Moreover, during 2008 the share of non-guaranteed MBS labeled held-tomaturity rose strongly from $8.3 \%$ to $11.7 \%$. During that year, the share of guaranteed MBS that is held-to-maturity, instead, fell from $6.5 \%$ to $6.0 \%$.

Classification of MBS as held-to-maturity increases the book value of assets if fair value is less than amortized cost. Figure 4 reports the mean ratio of fair value to amortized cost as reported by different banks over the sample period separately for guaranteed and non-guaranteed MBS (regardless of whether these securities are classified as held-to-maturity or available-forsale). We see that this ratio is fairly close to one for guaranteed MBS throughout the sample period. For non-guaranteed MBS, however, fair values relative to amortized cost declined from one in 2001 to $87.1 \%$ on average at end-2008. The increased classification of non-guaranteed MBS as held-to-maturity during 2008 (as seen in Figure 3) has thus tended to boost the overall book value of banks' MBS assets.

Although the market value of most banks' equity declined sharply in 2008, banks' regulatory capital, as measured by the ratio of Tier 1 capital to total risk-weighted assets, has remained fairly stable throughout the sample period. Figure 5 shows the development of the Tier 1 capital ratio and the share of Tier 1 capital in total bank capital. While leverage increased for some banks, consistent with findings by Adrian and Shin (2008), the average ratio of Tier 1 capital to total assets decreased only modestly from $12.2 \%$ in 2001 to $11.1 \%$ in $2008 .{ }^{16}$ The composition of capital also altered only modestly over the sample period, with the share of Tier 1 capital in total capital shrinking from $88.2 \%$ in 2001 to $86.3 \%$ in 2008 . This suggests that, although some banks have looked for less traditional, non-core sources of capital, such as

\footnotetext{
${ }^{15}$ Note that these guarantees tend to cover underlying repayment of interest and principle, but not valuation risk stemming from interest rate changes or mortgage prepayment.

${ }^{16}$ Tier 1 capital represents the core component of capital for banks and is regarded as the key measure of a bank's financial strength from a regulator's point of view. Tier 1 capital consists primarily of common stock, retained earnings, and disclosed reserves.
} 
subordinated debt or perpetual stock, to boost capital and increase assets, most banks continued to do so while increasing Tier 1 capital and maintaining excess regulatory capital.

A bank's $q$ should be close to one in a world where all bank assets and liabilities are readily tradable and marked to market. At the same time, deviations of $q$ from one can be explained by discrepancies between market values and book values of any bank balance sheet items. Below, we relate a bank's $q$ to a range of bank balance sheet items to explain bank-level variation in $q$. Variable market values of bank balance sheet items in an environment of slowly adjusting book values suggest that the dependence of $q$ on bank balance sheet items varies over time. It is especially interesting to assess whether the valuation of bank balance sheet items implicit in bank stock prices differs from book values at a time of financial crisis. Therefore, the emphasis of the empirical work will be on the year 2008, the year following the onset of the U.S. mortgage default crisis.

Summary statistics for the main variables in 2008 are provided in Table 1. We exclude banks with Tobin's $q$ exceeding its $99^{\text {th }}$ percentile (amounting to a Tobin's $q$ greater than 1.5) as these are not ordinary banks that carry primarily financial assets. The mean ratio of loans to assets is $71.4 \%$, while the mean ratio of real estate loans to assets is $53.6 \%$. The ratio of securities to assets (using amortized cost to value held-to-maturity securities and fair values for securities available-for-sale) is $16.9 \%$. As a subcategory, the average ratio of MBS to assets is 9.6\%. This can be split into MBS held-to-maturity at $0.8 \%$ of assets, and MBS available-for-sale at $8.8 \%$ of assets. MBS that are held-to-maturity can again be split into guaranteed and nonguaranteed securities equivalent to $0.7 \%$ and $0.1 \%$ of assets, respectively. Guaranteed and nonguaranteed MBS that are available-for-sale in turn amount to $8.0 \%$ and $0.8 \%$ of assets.

Next, Large bank is a dummy variable that equals one if a bank's total assets exceed the sample average total assets in a given quarter, and zero otherwise. HPI is a state-level house price index from the U.S. Office of Federal Housing Enterprise Oversight (OFHEO). Low valuation is a dummy variable that equals one in a given quarter if a bank's $q$ is less than one, and zero otherwise. By the end of $2008,60 \%$ of U.S. banks had a value of $q$ of less than one.

Several additional asset categories are considered as well. Trading is defined as trading assets relative to total assets (obtained from Schedule HC-B of the Call report). Trading assets, which include some MBS, are carried at fair value and held in the bank's trading book. ${ }^{17} \mathrm{~A}$ detailed split-up of trading assets is only available for the domestic offices of bank holding companies and is not reported. On average, trading assets only amount to a share of $0.5 \%$ of assets, because only large banks tend to have such assets.

Among bank liability variables, Deposits is defined as total deposits divided by total assets, and it amounts to $72.0 \%$ of assets on average. These deposits include relatively stable retail deposits and more unstable wholesale deposits. Data on deposits are obtained from Schedule HC-E of the Call report files. As an index of unstable wholesale deposits, we construct

\footnotetext{
${ }^{17}$ Trading assets are to be reported only by bank holding companies with average trading assets of $\$ 2$ million or more in any of the four preceding quarters.
} 
the ratio of deposits that exceed $\$ 100,000$ and have a remaining maturity of less than one year to total assets. These large and short-term deposits on average are $2.5 \%$ of assets. Banks are further seen to issue relatively little commercial paper, with commercial paper amounting to only $0.1 \%$ of assets on average. Bank capital, being the sum of Tier 1 and Tier 2 capital, is composed mostly of Tier 1 capital, amounting to $86.3 \%$ of capital on average.

Off-balance sheet items can equally matter for bank valuation. However, we find that they tend to constitute a small fraction of total assets for the average bank, in part because only large banks tend to have significant off-balance exposure. ${ }^{18}$ Data on off-balance sheet items are obtained from Schedule HC-L of the Call report files. Credit derivatives positive and Credit derivatives negative are the mean ratios of credit protection purchased and credit protection sold to total assets, respectively. These ratios are equivalent to $1.5 \%$ and $1.4 \%$ of assets.

We also obtain information on banks' securitization and asset sale activities from Schedule HC-S of the Call report files. The variable Securitized is the ratio of assets sold and securitized with servicing retained by the bank, or with recourse or other seller provided credit enhancements, to total assets. Securitized takes on a value of $1.5 \%$ of assets on average. Asset sales stands for the ratio of assets sold with recourse or other seller-provided credit enhancements but not securitized to total assets, and takes on a mean value of $3.2 \%$ of assets. The mean values of these off-balance sheet items are seen to be small on average and they are expected to affect bank valuation correspondingly little.

Next, loan loss provisioning is calculated as loan loss provisions divided by the book value of all loans. The mean loan loss provisioning rate is $0.8 \%$. Net charge-offs, in turn, is the ratio of the difference between loan charge-offs and loan recoveries to the book value of loans. The mean net loan charge-off rate is $0.5 \%$. Thus, loan loss provisioning exceeded net loan charge-offs in 2008, as expectations of additional loan losses surpassed actual loan write-offs. Finally, the share of real estate loans is the ratio of real estate loans to total loans with a mean value of $74.3 \%$.

\section{MARKET DISCOUNTS AND VALUATION EFFECTS OF REAL ESTATE RELATED ASSETS}

This section first provides empirical estimates of market discounts of real estate related assets relative to book values. Subsequently, it examines bank stock price reactions to amendments of fair value accounting rules. Finally, it investigates the use of banks' discretion regarding the accounting for bad loans in the form of loan loss provisioning and loan charge-offs.

\section{A. Empirical Evidence on Market Discounts}

This subsection reports the results of regressions of $q$ to reveal implicit stock market valuations of key balance sheet and off-balance sheet items. All regressions include U.S. state

\footnotetext{
${ }^{18}$ It should also be noted that only banks with off-balance sheet exposures in excess of certain minimum values are required to report these exposures.
} 
fixed effects and quarterly period fixed effects to control for systematic differences across U.S. states and time periods, such as housing and labor market conditions, or the monetary policy stance.

To start, Table 2 reports regressions of $q$ that include the overall loans and overall securities variables with data for 2008. ${ }^{19}$ The Securities variable enters with a positive coefficient of 0.096, which suggests that overall securities are valued more highly implicit in bank share prices than on banks' books, though the effects is not statistically significant. The Loans variable also does not enter significantly.

Next, regression 2 in addition includes the real estate loans and MBS variables. Note that the inclusion of both the Real estate loans variable and the Loans variable, which includes real estate loans, implies that the effect of real estate loans is measured relative to that of other loans. Similarly, for MBS, the effect is computed relative to the overall effect for Securities, since MBS are a part of total securities. The real estate loans variable enters with a coefficient of -0.107 that is significant at the $1 \%$ level implying that the discount of real estate loans (relative to other loans) is $10.7 \%$. The direct effect of real estate loans on Tobin's $q$, computed by adding the coefficients of the Loans and Real estate loans variables, is close to zero, indicating that non-real estate loans carry a negative discount. The MBS variable similarly enters with a coefficient of 0.244 that is significant at the $1 \%$ level so that MBS appear to be discounted $24.4 \%$ relative to other securities. ${ }^{20}$

In regression 3, we replace the MBS variable with two separate variables, MBS, held and MBS, for sale that represent the parts of MBS that are held-to-maturity (and carried at amortized cost) and available-for-sale (and carried at fair value). The MBS, held variable obtains a coefficient of -0.321 that is significant at $1 \%$, while the MBS, for sale variable enters with a coefficient of -0.227 that is significant at $5 \%$. Thus, MBS classified as held-to-maturity appear to be discounted significantly at $32.1 \%$, while the MBS available-for-sale tend to have a smaller discount of $22.7 \%$ on average relative to other securities. Thus, the gap between implicit market prices and accounting values appears to be largest for MBS classified as held-to-maturity.

Finally, in regression 4 we split the MBS, held and MBS, for sale variables into their guaranteed and non-guaranteed parts. Now we see that the guaranteed and non-guaranteed parts of the MBS, held variable are estimated with coefficients of -0.293 and -0.472 that are both significant at the $1 \%$ level, while the two MBS, for sale variables obtain negative coefficients of -0.220 and -0.324 that are smaller in absolute value. Thus, especially the non-guaranteed MBS

\footnotetext{
${ }^{19}$ The estimation model implicitly sets the discount on excluded asset categories to zero. Asset categories excluded from the regression are cash-like assets, including cash and federal funds sold and amounting to $9 \%$ of total assets, and non-cash like assets, including trading assets and fixed assets and amounting to the remainder of $2 \%$ of total assets. Thus, with cash-like assets carrying a discount of close to zero and constituting the majority of excluded assets, the implicit assumption of a discount of zero on excluded asset categories appears to be reasonable.

${ }^{20}$ We only consider the market valuation of MBS as implicit in share prices. Empirical models of the direct pricing of MBS are offered by Dunn and Singleton (1983), Boudoukh et al. (1997), and Schwartz and Torous (1989).
} 
classified as held-to-maturity are discounted (relative to securities other than MBS). The implied discount of $47.2 \%$ for these non-guaranteed MBS is sizeable.

The evidence thus points at sizeable market discounts on real-estate related assets relative to book values for U.S. bank holding companies in 2008. As we have data from 2001 onward, it is interesting to see whether such discounts existed before 2008. For this purpose, we re-estimate regression 3 of Table 2 with data for each of the years in the period 2001-2007. The results are reported in Table 3.

Throughout the period 2001 to 2004, none of the real estate asset categories is estimated with a significant discount. From 2005, the real estate loan variable obtains increasingly negative coefficients of $-0.074,-0.081$ and -0.101 that are significant at the $1 \%$ level to indicate a gradual deterioration of the implicit market value of real estate loans relative to book value. The MBS variables, however, are not estimated with significant discounts throughout the 2001-2007 period. The deterioration of real estate loans thus appears to have preceded the deterioration of MBS by several years, until in 2008 both asset categories are estimated with significant discounts.

We want to make sure that our results are not entirely driven by the size of the bank. To this end, we re-estimate regression 3 of Table 2 separately for small and large banks by splitting the sample based on the Large bank variable. The results are reported in regressions 1 and 2 of Table 4.

Except for the influence of Loans and Real estate loans, we find little difference in the estimated coefficients of the real-estate related variables for small and large banks. The discount on real estate loans is estimated to be $15.1 \%$ and significant at the $1 \%$ level for large banks, while the discount is estimated to be insignificant for small banks. At the same time, non-real estate loans are estimated to carry a premium for small banks. The estimated coefficient on the MBS, held variable is somewhat more negative for small banks, although this variable enters with statistically significant coefficients for both small and large banks. The estimated coefficient on the MBS, for sale variable is more negative for large banks than for small banks.

In regression 3 we again consider the full sample of banks but include interaction terms of the real estate loans and MBS variables with the Large bank dummy variable that denotes whether the bank is large or small. The regression confirms that the influence of real estate loans is statistically different for large banks compared to small banks. Specifically, the discount on real estate assets is estimated to be $12.7 \%$ larger for large banks. The estimated discounts for the MBS variables, on the other hand, turn out not to be statistically significantly different between small and large banks.

So far, we have focused on loans and securities and their real estate components. This emphasis is justified by the fact that loans and securities together comprise on average $88.3 \%$ of bank assets in 2008, and by the fact that real estate assets have suffered from house price declines during the recent financial crisis. Nevertheless, it is interesting to include other on- and off-balance sheet items in the analysis as well. 
To start, regression 1 of Table 5 includes several additional asset categories in regression 4 of Table 2. We split the MBS variables into their guaranteed and non-guaranteed parts but this does not affect the results. The regressions results indicate that non-guaranteed and held-tomaturity MBS are discounted the most. Trading, denoting the ratio of trading assets to total assets, enters the two regressions with negative but insignificant coefficients. The imprecise estimation of the coefficient on the trading variable could reflect that trading assets, in fact, include many diverse assets and on average comprise only $0.5 \%$ of total assets in 2008 .

Next, regression 2 of Table 5 includes several liability variables. First, Deposits stands for the ratio of total deposits to total assets. We expect this variable to carry a positive coefficient because banks extract value from the government guarantee on deposits in the presence of deposit insurance that is increasing in the amount of deposits. Indeed, we find that this variable obtains a positive though insignificant coefficient. Second, Deposits, large, short-term stands for the ratio of deposits in excess of $\$ 100,000$ and with a remaining maturity of one year or less to total assets. These large and short-term deposits can be considered part of the wholesale funding of a bank. The supply of this type of bank funding may be unstable, not least because deposits in excess of $\$ 100,000$ are traditionally not covered by deposit insurance. This variable enters with a coefficient of -0.157 that is significant at the $5 \%$ level. This suggests that 1 dollar of these wholesale deposits reduces bank value by about 0.16 dollars (more than other deposits). This, of course, does not mean that the market value of these deposits is substantially different from unity. Rather, a bank that heavily relies on wholesale funding is exposed to considerable funding risk as potentially reflected in bank share prices. Third, the commercial paper variable stands for the ratio of issued commercial paper to total assets. This variable enters with a positive but insignificant coefficient.

Regression 3 includes a variable that captures the composition of equity capital. Specifically, we include the share of Tier 1 capital in total capital, denoted by the Tier 1 variable. We expect that this variable enters with a positive coefficient, especially for the year 2008, as markets have reassessed the superior value of Tier 1 capital to Tier 2 capital, partly in response to stricter capital requirements proposed by regulators. We indeed find that the Tier 1 capital variable enter with positive coefficients of 0.105 that is significant at the $1 \%$ level. This suggests that a one standard deviation increase of $10 \%$ in the share of Tier 1 capital in total capital increases bank value by $1 \%$, which is not irrelevant given a standard deviation of $q$ of $5 \%$. Interestingly, in unreported regressions we find that prior to 2008 the effect of the share of Tier 1 capital on $q$ is not statistically significant, indicating that Tier 1 or core capital became a highly valued component of bank capital only starting in 2008.

We next include several off-balance sheet items in regression 4, including information on credit protection purchased or sold, asset securitization, and asset sales. ${ }^{21}$ None of these offbalance sheet variables enter significantly, possibly reflecting the fact that they constitute only a small fraction of bank's assets.

\footnotetext{
${ }^{21}$ The variables in the expression for $q$ remain defined as shares of the value of on-balance sheet assets.
} 
Comparing the results of regression 4 in Table 2 with those of regression 4 in Table 5, we see that the inclusion of additional balance sheet variables reduces estimated coefficients for the loans and securities variables and renders these variables insignificant. Thus, the implicit stock market valuation of non-real estate loans and securities does not differ significantly from book valuation in Table 5. Real estate related variables, however, continue to obtain negative and significant coefficients. The negative and significant coefficient on the real estate loan variable implies that real estate loans are discounted relative to non-real estate loans as well as relative to book values. Similarly, MBS that are held-to-maturity and available-for-sale are discounted relative to non-MBS securities and relative to book values.

One concern is that our results are driven by an overshooting in asset prices, meaning a temporary deviation in value from fundamental value. However, our measure of firm value is based on equity prices, which reflect the consensus view of many financial market participants. While fire sales and illiquidity may have led to overshooting in some asset markets, notably the market for derivatives on mortgage-backed securities, stock markets continued to be liquid throughout 2008. We therefore maintain that stock market prices offer the best available information on the value of banks, and conclude that the accounting values of real estate related assets on the books of banks were inflated in 2008.

\section{B. Banks' Stock Price Reaction to Amendments of Fair Value Accounting Rules}

Thus far, we have studied the impact of banks' asset composition on the valuation of banks to gauge the market discounts implicit in different assets. Differences in such market discounts partly reflect differences in accounting treatment. In this section, we assess how recent changes to accounting rules have affected the valuation of banks by studying the immediate stock price reaction to the announcements of these rule changes.

On October 10, 2008, the FASB clarified rules for determining the fair value of a financial instrument applying Financial Accounting Standard (FAS) 157 when the market for that financial asset is not active. ${ }^{22}$ The clarification made explicit that the use of a bank's own assumptions about future cash flows and appropriately risk-adjusted discount rates is acceptable when relevant observable inputs into value calculation are not available. Also, it was made clear that broker (or pricing service) quotes may be appropriate input when measuring fair value. ${ }^{23}$ These announced interpretations of FAS 157 were seen to provide banks with more discretion in determining the fair value of securities and to enable them to limit markdowns in the face of illiquid securities markets during the U.S. mortgage default crisis.

\footnotetext{
22 These rules, issued under Final Staff Position on FAS 157-3, were effective upon issuance, including prior periods for which financial statements have not been issued.

${ }^{23}$ The Office of the Chief Accountant of the U.S. Securities and Exchange Commission (SEC) and the FASB staff had already jointly issued a press release on September 30, 2008, that addresses similar application issues of FAS 157. See http://www.fasb.org/news/2008-FairValue.pdf for further details.
} 
Subsequently, on April 9, 2009 the FASB approved amendments to FAS 157 that give banks more discretion in using non-market information to determine fair values of securities. ${ }^{24}$ In practice, firms will be allowed to re-classify level 2 assets, which were previously valued using proxy reference market prices, to level 3 assets, whose valuation is model-based. ${ }^{25}$ By providing greater flexibility in excluding illiquid transactions from level 2 fair value determination, the new rules effectively expand the scope for firms to prevent significant mark-downs in illiquid markets subject to great price declines, and possibly to mark-up assets that had been aggressively written down previously. ${ }^{26}$ Both the October 2008 and April 2009 announcements of the FASB were seen by market commentators as efforts to artificially prop up the accounting value of banks. While resulting in a decrease in transparency and information disclosure, these changes are expected to be cheered by shareholders of distressed banks, because the reduction in writedowns allows such banks to maintain regulatory capital requirements.

We use a standard event study methodology to compute the average price effect on bank shares of these announcements of changes in accounting rules. Also, we assess whether the share prices of different types of banks reacted differently to these announcements. In particular, we examine whether abnormal returns vary by bank size and the degree to which banks hold MBS. We use a standard market model to estimate abnormal returns.

Table 6 reports the event study results for the October 10, 2008 announcement. Cumulative abnormal returns are based on a market model with estimation window of [t-250, $\mathrm{t}$ 30], where $t$ denotes October 10, 2008, and time is counted in trading days. We use the total return on the S\&P 500 as proxy for the daily market return. We report results for two different event windows. Panel A reports results using an event window of $(t-3, t+2]$, where $t$ denotes October 10, 2008, and time is counted in trading days, while Panel B reports results using an event window of $(t-1, t]$. Using such a short event window of a single day is acceptable given the high stock market volatility around the time of this event, culminating in a stock market crash. To mitigate concerns that returns from illiquid firms are driving the result, we exclude from the sample observations from firms with more than 100 zero returns over the estimation window or a zero return on the event date.

Average cumulative abnormal returns are reported both for the full sample of banks and for different subsamples of banks, with sample splits based on a host of bank characteristics, specifically bank size and the degree to which banks hold MBS. The sample splits are as follows:

\footnotetext{
${ }^{24}$ The changes became effective for financial statements ending June 2009, with early adoption permitted for firstquarter 2009 results.

${ }^{25}$ See http://www.fasb.org/news/nr040909.shtml for further details.

${ }^{26}$ On the same day, new accounting rules were announced that will reduce the level of losses to be disclosed in firms' income statements for available-for-sale and held-to-maturity debt securities. Under the old rules, provided the firm had the "intent and ability to hold" the security until recovery, "other-than-temporary" impairment would need to be recognized in the income statement. Under the new rules, provided the firm "does not have the intent to sell" the security, it only needs to recognize the credit component of the other-than-temporary impairment in income, while recording the remaining portion in a special category of equity ("other comprehensive income"). The change from "intent and ability to hold" to "no intention to sell" may provide sufficient flexibility to significantly reduce the level of total impairment, of which only the credit component is deducted from income.
} 
Large (small) denotes firms with total assets above (below) the quarterly sample median; and High (Low) share of MBS denotes firms with MBS as a fraction of total assets above (below) the quarterly sample median. We use third quarter 2008 Call report data to construct these bankspecific variables, while daily total return data on equities are obtained from Datastream.

Table 7 reports event study results for the second event on April 9, 2009. Again, we report results separately for two different event windows in Panels A and B. To avoid valuation effects arising from events that occurred during the period following the announcement of the first event, including the first event itself, from biasing the market model induced estimates of normal returns, we apply the same estimation window as used in the first event study to estimate normal returns.

The cumulative abnormal returns (CAR) are large on the event day itself for both events but in the case of the first event, the average CAR across all banks is much lower and barely significant if we extend the event window. The reason is that October 10, 2008 was the only day that week during which the stock market experienced positive returns in what otherwise was a rapidly falling market, in which the prices of bank stocks were falling more sharply than those of non-bank stocks.

The sample splits reveal a number of interesting differences in the valuation effect across different types of banks. The CAR of large banks is consistently higher and economically large. One explanation for this result is that larger U.S. banks tend to have a larger fraction of hard-tovalue assets, including off-balance sheet, and thus tend to benefit most from the changes in accounting rules. The share price of banks with a large fraction of MBS also reacts favorably to the relaxation of fair value accounting, at least for the October 10, 2008 event, as expected.

Overall, we find that the valuation of large banks and banks with a large fraction of MBS gains relatively much on account of both announcements. This can be explained by the fact that these banks have relatively many assets such as MBS that are affected by more lenient rules regarding the calculation of their fair value.

\section{ACCOUNTING DISCRETION ON IMPAIRED ASSETS AND ASSET CLASSIFICATION}

In this section, we assess the relevance of banks' discretion in accounting for bad loans and in classifying MBS into categories that render more favorable accounting values. Together with the valuation results presented in section 4, these results shed light on the reliability of banks' financial statements, and in particular on the extent to which book values of banks' assets accurately account for future asset impairment.

\section{A. Accounting discretion on accounting for bad loans}

The relative importance of real estate assets in the average bank's portfolio renders bank capital very sensitive to the performance of real estate loans. In case of expected future loan losses, a bank needs to provision for these losses. Provisioning for loan losses, however, reduces 
income and regulatory capital. Thus, distressed banks may be tempted to provision relatively less for real estate loans or any other loans in an attempt to overstate capital. ${ }^{27}$

In this subsection, we report regressions that test whether distressed banks report relatively low loan loss provisions. To capture loan loss provisioning, we construct the ratio of loan loss provisions to total loans. ${ }^{28}$ We obtain data on loan charge-offs and provisions from Schedule HI-B of the Call report files.

In regression 1 of Table 8 , the loan loss provisioning variable is first related to the share of real estate loans in total loans. We expect loan loss provisioning to be positively related to the share of real estate loans, as these loans have been particularly affected by recent house price declines. The share of real estate loans indeed enters the regression with a positive coefficient, but it is statistically insignificant.

Banks that need to absorb large losses arising from exposure to MBS may lower their provisioning standards in an effort to preserve capital. As a proxy for potential losses arising from exposure to MBS, we use the ratio of MBS to assets denoted MBS. This exposure variable obtains a negative coefficient of -0.015 that is statistically significant at the $5 \%$ level, suggesting that banks with large MBS exposure tend to attenuate reported loan loss provisions.

We expect that the incentive to hold back on loan loss provisioning is particularly pronounced for distressed banks. Regressions 2 and 3 therefore re-estimate regression 1 for subsamples of banks with below-median and above-median $q$, respectively. Regression 2 confirms a negative and statistically significant coefficient for the MBS variable for lowvaluation banks, while the coefficient for the MBS variable is negative but insignificant in regression 3. Thus, low-valuation banks appear to be the ones that compensate for their MBS exposure by scaling back their loan loss provisioning.

Distressed banks also may be slow in recognizing losses on their real estate loan portfolio in the form of write-downs ${ }^{29}$ or charge-offs. ${ }^{30}$ To analyze this, regressions 4 to 6 take as dependent variable the ratio of net charge-offs to loans (where net charge-offs are the difference between charge-offs and recoveries). Otherwise, these regressions are similar to regressions 1 to 3. Consistent with the earlier results, we now find that the ratio of net charge-offs to loans is negatively related to the MBS variable, though the effect is not statistically significant.

\footnotetext{
${ }^{27}$ Previously, Moyer (1990) and Ahmed et al. (1999) have found that banks use their discretion regarding loan loss provisioning to manage their capital. Docking et al. (1997) consider the information and contagion effects of bank loan loss reserve announcements.

${ }^{28}$ No breakdown of loan loss provisioning for real estate loans and other loan categories is available from banks' Call reports.

${ }^{29}$ Loan writedowns include writedowns arising from transfers of loans to a held-for-sale account.

${ }^{30}$ Loan charge-offs reduce allowances for loan losses rather than bank capital if previous loan loss provisions were made. In any case, charge-offs may trigger further loan loss provisioning which reduces regulatory capital.
} 
In sum, we find evidence that low-valuation banks with large MBS exposures hold back on their loan loss provisioning.

\section{B. Classification of Mortgage-Backed Securities}

According to FAS 159, banks have the option to classify securities as held-to-maturity or available-for-sale. Securities are to be classified as held-to-maturity and carried at amortized cost, if management has the intention to hold them until maturity. Otherwise, securities are available-for-sale and carried at fair value. This classification is to be made on the date of purchase of the security and it is in principle irreversible. However, banks can achieve some reclassification of previously acquired securities in compliance with FAS 159 by selling and buying equivalent securities that are categorized differently within the same reporting period.

On the purchase date, amortized cost and fair value should be essentially the same and hence no valuation advantage can be obtained by classifying securities either way. ${ }^{31}$

Reclassification of previously acquired securities potentially does affect the overall book value of securities. Specifically, overall book value rises if available-for-sale securities are reclassified as held-to-maturity at a time when amortized cost exceeds fair value. In 2008, the mean ratio of fair value to amortized cost for non-guaranteed MBS was 0.927 , against a mean ratio of fair value to amortized cost for guaranteed MBS of 1.005 (see Figure 4). These accounting valuations gave banks an incentive to classify non-guaranteed MBS as held-to-maturity to the extent possible. We now examine whether banks, and especially distressed banks, responded to this incentive by classifying a larger fraction of their MBS as held-to-maturity.

Table 9 reports regressions of the shares of MBS that are held-to-maturity for guaranteed as well as non-guaranteed securities. In the calculation of these shares, the MBS that are actually available-for-sale are also valued at amortized cost. The number of observations differs depending on whether the dependent variable is computed for guaranteed or non-guaranteed securities because a significant fraction of banks reports not to have any non-guaranteed MBS. The fraction of MBS that is held-to-maturity increased from $7.5 \%$ at end-2007 to $11.7 \%$ at end2008, consistent with the notion that banks had incentives during the year 2008 to classify a larger fraction of their MBS as held-to-maturity (see Figure 3).

The regression 1 results indicate that the share of guaranteed MBS classified as held-tomaturity is positively but insignificantly related to both the real estate loans and the overall MBS (valued at amortized cost) to assets variables. In regression 2, we see that the non-guaranteed share of MBS that is held-to-maturity is positively and insignificantly related to the MBS, amortized cost variable but positively and significantly to the real estate loans variable with a coefficient of 0.731 .

\footnotetext{
${ }^{31}$ A consideration guiding this classification at the time of securities acquisition can be to obtain an appropriate mix of assets and liabilities that are carried at fair value.
} 
Thus, we find evidence that banks pressured by real estate exposure tend to report a relatively large share of non-guaranteed MBS as held-to-maturity, and that this effect operated chiefly through exposure to real estate loans rather than MBS.

Regressions 3 and 4 differ from regressions 1 and 2 in that we include the Low valuation variable as an additional variable to assess differences in the classification of MBS between banks with high or low $q$. The Low valuation variables enters both regressions with a positive but insignificant coefficient, indicating that there is no significant difference between high and low valuation banks in the fraction of non-guaranteed MBS that they report as held-to-maturity.

Finally, regressions 5 and 6 differ from regressions 3 and 4 in that we include interaction terms of the real estate exposure variables and the Low valuation variable. Positive estimated coefficients imply that especially banks with below-average $q$ report a larger share of their MBS as held-to-maturity in response to large real estate exposures. Indeed, the interaction terms in regressions 5 and 6 all enter with positive estimated coefficients, although the coefficients are statistically significant only for the interaction with the MBS variable in regression 6 . This suggests that banks with below-average $q$ increase the share of non-guaranteed MBS that is heldto-maturity to a relatively large extent in response to real estate exposures. This is to be expected as the gains in terms of the book value of assets are relatively large in the case of non-guaranteed MBS, as for these securities the ratio of fair value to amortized cost was relatively low in 2008.

Next, we examine whether banks have also exploited discretion in the classification of their MBS with a view to boost the accounting value of their assets prior to 2008. To do this, we re-estimate regression 4 of Table 9 with data for the period 2001-2007. A focus on nonguaranteed MBS is justified, as the ratio of fair value to amortized cost of these MBS deviates relatively frequently from unity as seen in Figure 4. In 2001, for instance, fair values of nonguaranteed MBS tended to exceed amortized cost. The results are presented in Table 10.

The MBS, amortized variable enters the regressions in Table 11 with either negative or positive coefficient, depending on the year, although none of these estimated coefficients is statistically significantly different from zero. The real estate loan variable enters with positive coefficients that are significant at the $5 \%$ level from the year 2005 onwards, suggesting that banks with large real estate exposure classified a larger fraction of their non-guaranteed MBS as held-to-maturity. Over the 2002-2008 period, the real estate loans variable increases in a nonmonotonic way from 0.137 to 0.457 .

Turning to the Low valuation variable, we find that this variable enters with positive but insignificant coefficients for the years 2001 through 2004 that turn negative from the year 2005 onwards. Overall, these results confirm that already prior to 2008 banks classified their nonguaranteed MBS with a view to boasting the book value of these assets.

\section{CONCLUSIONS}

In 2008, the majority of U.S. banks were zombie banks as evidenced by market values of bank assets being lower than their book values. This is prima facie evidence that the book value of banks' balance sheets is inflated. We find that the stock market attaches less value to real 
estate loans and MBS than their accounting values. This discrepancy between the accounting and market value of bank assets suggests that banks have been slow to adjust the book value of their assets to conform to market expectations about future declines in asset performance.

We further find a larger discount for held-to-matury MBS (that are carried at amortized cost) than for available-for-sale MBS (that are carried at fair value), suggesting that fair values recognize the impairment of MBS to a greater extent than amortized costs do.

We estimate valuations implicit in bank share prices for a range of bank liabilities and off-balance sheet items as well. Bank share prices are found to negatively reflect bank funding in the form of large and short-term deposits. This may reflect that wholesale funding of this type exposes the bank to considerable funding risks. Bank share prices are further found to be affected by off-balance sheet items such as credit insurance bought and sold, as well as credit commitments to own and other financial institutions' securitization structures.

While we do not directly address the issue of procyclicality of fair value accounting, we find that at a time of depressed asset prices such as in 2008, one year into the U.S. mortgage crisis, the stock market applies discounts to banks that are larger than those implicit in the fair values of MBS. This suggests that fair value accounting, as currently implemented, is still less procyclical than any accounting based exclusively on stock market valuations would be. ${ }^{32}$

In October 2008 and April 2009, the FASB announced sets of accounting rule amendments providing banks with additional discretion in the determination of fair value of securities in case markets are illiquid and transaction prices may result from 'fire sales'. On both occasions, banks with large exposures to MBS are found to have experienced relatively large excess returns. Additional discretion in the determination of fair values in an environment of depressed asset prices makes it easier for banks with large affected exposures to maintain accounting solvency, which is apparently cheered by bank equity investors.

This paper further demonstrates that banks with large exposures to MBS systematically use their accounting discretion so as to inflate asset values and book capital. Specifically, banks with large exposure to MBS are found to report relatively low loan loss provisioning rates and loan charge-off rates, and at the same time they tend to classify a relatively large share of their MBS as held-to-maturity, to be able to carry these assets at amortized costs.

Our finding that distressed banks tend to exploit their discretion in loan loss provisioning, loan charge-offs, and classification of MBS to boost their accounting value should be reason for concern, as it implies that the discretion implicit in current accounting rules leads to systematic biases in valuations on bank balance sheets. Accounting discretion enables banks with impaired

\footnotetext{
${ }^{32}$ At any rate, in our view the main task of accounting systems is to provide reliable information, and this goal should not be compromised by concerns about any procyclicality of credit supply. A common view is that bank regulation should target any undesirable credit procyclicality directly, for instance by prescribing cyclical capital requirements (for a more detailed discussion of this debate, see Laeven and Majnoni, 2003, Kashyap and Stein, 2004, and Repullo and Suarez, 2008).
} 
asset portfolios to satisfy capital adequacy requirements, but it makes it difficult to assess the true health of the affected banks.

Replacing the mixed attribute model of accounting with a model based entirely on fair value accounting will mitigate incentives for accounting arbitrage and could serve to improve the information value of public accounts, even if fair value calculations themselves are also subject to discretion by banks. Similarly, a more forward-looking approach to provisioning for bad loans on an expected loss basis could improve the information content of bank accounting, although incentives for banks to use discretion on loan loss provisioning rates to inflate the book value of assets during economic downturns would remain.

No accounting system of disclosing the fair value of financial assets will be perfect. Models can be misused or misinterpreted. But reasonable and auditable methods exist today to incorporate information embedded in market prices. More reliable public accounts are beneficial to regulatory and market discipline and could potentially have helped to avoid some of the losses that banks currently face. 


\section{REFERENCES}

Adrian, Tobias, and Hyun S. Shin, 2008, "Liquidity and Leverage," Journal of Financial Intermediation, forthcoming.

Ahmed, Anwer S., Carolyn Takeda, and Shawn Thomas, 1999, "Bank Loan Loss Provisions: A Reexamination of Capital Management, Earnings Management and Signaling Effect," Journal of Accounting and Economics Vol. 28, pp. 1-25.

Allen, Franklin, and Elena Carletti, 2008, "Mark-to-Market Accounting and Liquidity Pricing," Journal of Accounting and Economics Vol. 45, pp. 358-78.

Barth, James R., Gerard Caprio, and Ross Levine, 2006, "Rethinking Bank Regulation,” Cambridge: Cambridge University Press.

Barth, Mary E., William H. Beaver, and Wayne R. Landsman, 1996, "Value-relevance of Banks' Fair Value Disclosures Under SFAS,” No. 107, Accounting Review, pp. 513-37.

— , 2001, "The Relevance of the Value Relevance Literature for Financial Accounting Standard Setting: Another View," Journal of Accounting and Economics Vol. 31, pp. 77-104

Berger, Allen, Sally M. Davies, and Mark J. Flannery, 2000, "Comparing Market and Regulatory Assessments of Bank Performance: Who Knows What When?" Journal of Money, Credit and Banking, Vol. 32 No. 3, pp. 641-67.

Bongini, P., L. Laeven, and G. Majnoni, 2002, "How Good is the Market at Aassessing Bank Fragility? A Horse race between different indicators," Journal of Banking and Finance, Vol. 26, pp. 1011-28.

Boudoukh, Jacob, Matthew Richardson, Richard Stanton, and Robert F. Whitelaw, 1997, "Pricing Mortgage-backed Securities in a Multifactor Interest Rate Environment: A Multivariate Density Estimation Aapproach," Review of Financial Studies Vol. 10, pp. 405-46.

Brown, Craig O., and I. Serdar Dinc, 2005, "The Politics of Bank Failures: Evidence From Emerging Markets," Quarterly Journal of Economics, Vol. 120 No. 4, pp. 1413-444.

— 2009, “Too Many to Fail? Evidence of Regulatory Forbearance When the Banking Sector is Weak," Review of Financial Studies, forthcoming.

Caballero, Ricardo, Takeo Hoshi, and Anil K. Kashyap, 2008, “ Zombie Lending and Depressed Restructuring in Japan,” American Economic Review Vol. 98, pp. 1943-977. 
Collins, Julie H., Douglas A. Shackelford, and James M. Wahlen, 1995, "Bank Differences in the Coordination of Regulatory Capital, Earnings, and Taxes," Journal of Accounting Research, Vol. 33 No. 2, pp. 263-91.

Dell'Ariccia, Giovanni, Deniz Igan, and Luc Laeven, 2008, "Credit Booms and Lending Standards: Evidence From the Subprime Mortgage Market," mimeo (Washington: International Monetary Fund).

Demyanyk, Yuliya, and Otto Van Hemert, 2008, "Understanding the Subprime Mortgage Crisis," Review of Financial Studies, forthcoming.

DeYoung, Robert and Chiwon Yom, 2008, "On the Independence of Assets and Liabilities: Evidence From U.S. Commercial Banks, 1990-2005," Journal of Financial Stability Vol. 4, pp. 275-303.

Docking, Diane Scott, Mark Hirschey, and Elaine Jones, 1997, "Information and Contagion Effects of Bank Loan-loss Reserve Announcements, Journal of Financial Economics "Vol. 43, pp. 219-39.

Dunn, Kenneth B., and Kenneth J. Singleton, 1983, “An Empirical Analysis of the Pricing of Mortgage-backed Securities, Journal of Finance Vol. 38, pp. 613-23.

Eccher, Elizabeth A., K. Ramesh, and S. Ramu Thiagarajan, 1996, "Fair Value Disclosures by Bank Holding Companies," Journal of Accounting and Economics Vol. 22, pp. 79-117.

Financial Stability Forum, 2008, Report on Enhancing Market and Institutional Resilience, April 2008. Available at: http://www.financialstabilityboard.org/

Freixas, Xavier, and Dimitrios Tsomocos, 2004, "Book vs. Fair Value Accounting in Banking, and Intertemporal Smoothing," Oxford Financial Research Centre working paper.

Fudenberg, Drew, and Jean Tirole, 1995, “A Theory of Income and Dividend Smoothing Based on Incumbency Rents," Journal of Political Economy, Vol. 103, pp. 75-93.

Goh, Beng Wee, Jeffrey Ng, and Kevin Ow Yong, 2009, "Market Pricing of Banks' Fair Value Assets Reported Under SFAS 157 During the 2008 Economic Crisis," Mimeo, MIT.

Heaton, Johan, Deborah Lucas, and Robert McDonald, 2009, "Is Mark-to-Marking Accounting Destabilizing? An Analysis and Implications for Policy,” mimeo, University of Chicago.

Holthausen, Robert W., and Ross L. Watts, 2001, "The Relevance of the Value-relevance Literature for Financial accounting Standard Setting," Journal of Accounting and Economics 2001, pp. 3-75.

Hutton, Amy P., Alan J. Marcus, and Hassan Tehranian, 2008, “ Opaque Financial Reports, R2, and the Distribution of Crash Risks," Journal of Financial Economics, forthcoming. 
International Monetary Fund, 2008, Global Financial Stability Report. Chapter 3: Fair Value Accounting and Procyclicality, October 2008.

Kane, Edward J., 1989, The S\&L Insurance Mess: How Did It Happen? Washington, D.C.: Urban Institute.

_ _ 2003, "Continuing Dangers of Disinformation in Corporate Accounting Reports," Review of Financial Economics, Vol. 13, pp. 149-64.

Karpoff, Jonathan M., D. Scott Lee, and Gerald S. Martin, 2008, “The Cost to Firms of Cooking the Books," Journal of Financial and Quantitative Analysis Vol. 43, pp. 581-612.

Kashyap, Anil, and Jeremy Stein, 2004, "Cyclical Implications of the Basel II Capital Standards," Federal Reserve Bank of Chicago Economics Perspectivesm $1^{\text {st }}$ quarter, pp. 18-31.

Keys, Benjamin, Tanmoy Mukherjee, Amit Seru, and Vikrant Vig, 2008, "Securitization and Screening: Evidence From Subprime Mortgage Backed Securities," Quarterly Journal of Economics, forthcoming.

Knaup, Martin, and Wolf Wagner, 2009, "A Market-based Measure of Credit Quality and Banks' Performance During the Subprime Crisis,” mimeo, Tilburg University.

Kolev, Kalin, 2009, "Do Investors Perceive Marking-to-Model as Marking-to-Myth? Early Evidence from FAS 157 Disclosure," mimeo, NYU Stern School of Business.

Kroszner, Randall S., and Philip E. Strahan, 1996, "Regulatory Incentives and the Thrift Crisis: Dividends, Mutual-to-Stock Conversions, and Financial Distress," Journal of Finance, Vol. 51, pp. 1285-1319.

Laeven, Luc, and Giovanni Majnoni, 2003, "Loan Loss Provisioning and Economic Slowdowns: too Much, too Late, Journal of Financial Intermediation Vol. 12, pp. 178-97.

Laeven, Luc, and Ross Levine, 2007, "Is There a Diversification Discount in Financial Conglomerates?” Journal of Financial Economics Vol. 85, pp. 331-67.

Landsman, Wayne, 2006, "Fair Value Accounting for Financial Instruments: Some Implications for Bank Regulation,” BIS Working Papers No 2009.

Lang, Larry, and Rene M. Stulz, 1994, “Tobin's q, Corporate Diversification, and Firm Performance," Journal of Political Economy Vol. 102, pp. 1248-280.

Laux, Christian, and Christian Leuz, 2009, “The Crisis of Fair Value Accounting: Making Sense of the Recent Debate," mimeo, Goethe University Frankfurt. 
Leuz, Christian, D.J. Nanda, and Peter Wysocki, 2003, "Investor Protection and Earnings Management: An International Comparison," Journal of Financial Economics, Vol. 69, pp. 505-27.

Leuz, Christian, and Peter Wysocki, 2008, "Economic Consequences of Financial Reporting and Disclosure Regulation: A Review and Suggestions for Future Research," mimeo, Chicago University and MIT.

Loutskina, Elena, and Philip Strahan, 2009, "Securitization and the Declining Impact of Bank Finance on Loan Supply: Evidence From Mortgage Originations," Journal of Finance, Vol. 64, pp. 861-89.

Mian, Atif, and Amir Sufi, 2008, “The Consequences of Mortgage Credit Expansion: Evidence from the 2007 Mortgage Default Crisis," Quarterly Journal of Economics, forthcoming.

Morgan, Donald P., 2002, "Rating Banks: Risk and Uncertainty in an Opaque Industry," American Economic Review Vol. 92, pp. 874-88.

Moyer, Susan E., 1990, "Capital Adequacy and Ratio Regulations and Accounting Choices in Commercial Banks,” Journal of Accounting and Economics Vol. 13, pp. 123-54.

Plantin, Guillaume, Haresh Sapra, and Hyun S. Shin, 2008, "Marking-to-Market: Panacea or Pandora's box?” Journal of Accounting Research Vol. 46, pp. 435-60.

Repullo, Rafael, and Javier Suarez, 2008, “The Procyclical Effects of Basel II,” CEPR Discussion paper No. 6862, CEPR, London.

Sachs, Jeffrey, and Harry Huizinga, 1987, "U.S. Commercial Banks and the Developing Country Debt Crisis," Brookings Papers on Economic Activity Vol. 2, pp. 555-606.

Sankar, Mandira R., and K. R. Subramanyam, 2000, "Reporting Discretion and Private Information Communication Through Earnings," Journal of Accounting Research Vol. 39, pp. 365-86.

Schwartz, Eduardo S., and Walter N. Torous, 1989, "Prepayment and the Valuation of Mortgage-backed Securities," Journal of Finance Vol. 44, pp. 375-92.

Shackelford, Douglas A., Joel B. Slemrod, and James M. Sallee, 2008, “A Unifying Model of How the Tax System and Generally Accepted Accounting Principles Affect Corporate Behavior," mimeo, University of North Carolina at Chapel Hill.

Song, Chang Joon, Wayne Thomas, and Han Yi, 2009, "Value Relevance of FAS 157 Fair Value Hierarchy Information and the Impact of Corporate Governance Mechanisms," mimeo, University of Oklahoma. 
Trueman, Brett, and Sheridan D. Titman, 1988, “An Explanation for Accounting Income Smoothing," Journal of Accounting Research, Vol. 26, pp. 127-39. 


\section{Appendix. Variable Definitions and Data Sources}

\begin{tabular}{|c|c|c|}
\hline Variable & Definition & Source \\
\hline Tobin's $q$ & $\begin{array}{l}\text { Ratio of market value of common equity plus book value of preferred equity and } \\
\text { liabilities to book value of assets }\end{array}$ & $\begin{array}{l}\text { Call report and } \\
\text { Datastream }\end{array}$ \\
\hline $\begin{array}{l}\text { Share of MBS held-to- } \\
\text { maturity, guaranteed }\end{array}$ & Share of guaranteed mortgage-backed securities (MBS) that is held-to-maturity & Call report \\
\hline $\begin{array}{l}\text { Share of MBS held-to- } \\
\text { maturity, not guaranteed }\end{array}$ & Share of non guaranteed MBS that is held-to-maturity & Call report \\
\hline Loans & Ratio of loans to assets & Call report \\
\hline Real estate loans & Ratio of real estate loans to assets & Call report \\
\hline Securities & $\begin{array}{l}\text { Ratio of securities to assets. Securities held-to-maturity are at amortized cost and } \\
\text { securities available-for-sale are at fair value }\end{array}$ & Call report \\
\hline Securities, amortized cost & $\begin{array}{l}\text { Ratio of securities to assets. Securities are at amortized cost if they are both held- } \\
\text { to-maturity and available-for-sale }\end{array}$ & Call report \\
\hline MBS & $\begin{array}{l}\text { Ratio of MBS to assets. Held-to-maturity securities are at amortized cost and } \\
\text { available-for-sale securities are at fair value }\end{array}$ & Call report \\
\hline MBS, amortized & $\begin{array}{l}\text { Ratio of MBS to assets. Both held-to-maturity and available-for-sale MBS are at } \\
\text { amortized cost }\end{array}$ & Call report \\
\hline MBS, held & Ratio of MBS that are held-to-maturity to assets & Call report \\
\hline MBS, for sale & Ratio of MBS that are available-for-sale to assets & Call report \\
\hline MBS, held, guaranteed & $\begin{array}{l}\text { Ratio of MBS that are held-to-maturity and issued or guaranteed by FNMA, } \\
\text { FHLMC, and GNMA to assets }\end{array}$ & Call report \\
\hline $\begin{array}{l}\text { MBS, held, not } \\
\text { guaranteed }\end{array}$ & Ratio of non-guaranteed MBS that are held-to-maturity to assets & Call report \\
\hline MBS, for sale, guaranteed & $\begin{array}{l}\text { Ratio of MBS that are available-for-sale and issued or guaranteed by FNMA, } \\
\text { FHLMC, and GNMA to assets }\end{array}$ & Call report \\
\hline $\begin{array}{l}\text { MBS, for sale, not } \\
\text { guaranteed }\end{array}$ & Ratio of non-guaranteed MBS that are available-for-sale to assets & Call report \\
\hline Large bank & $\begin{array}{l}\text { Dummy variable that is one if assets are above mean of assets in the data set and } \\
\text { zero otherwise }\end{array}$ & Call report \\
\hline HPI & State-level housing price index, rescaled to index value of 1 & OFHEO \\
\hline Low valuation & Dummy variable that equals 1 if Tobin's $q$ is less than 1 , and 0 otherwise & Call report \\
\hline Trading & Ratio of assets in trading account to total assets & Call report \\
\hline Deposits & Ratio of deposits to assets & Call report \\
\hline $\begin{array}{l}\text { Deposits, large, short- } \\
\text { term }\end{array}$ & $\begin{array}{l}\text { Ratio of time deposits of } \$ 100,000 \text { or more with a remaining maturity of one year } \\
\text { or less to assets }\end{array}$ & Call report \\
\hline Commercial paper & Ratio of commercial paper to assets & Call report \\
\hline Tier 1 & Ratio of tier 1 capital in total capital & Call report \\
\hline $\begin{array}{l}\text { Credit derivatives, } \\
\text { positive }\end{array}$ & $\begin{array}{l}\text { Ratio of notional amount of credit derivatives for which the bank is the } \\
\text { beneficiary (credit protection purchased) to assets }\end{array}$ & Call report \\
\hline $\begin{array}{l}\text { Credit derivatives, } \\
\text { negative }\end{array}$ & $\begin{array}{l}\text { Ratio of notional amount of credit derivatives for which the bank is the guarantor } \\
\text { (credit protection extended) to assets }\end{array}$ & Call report \\
\hline Securitized & $\begin{array}{l}\text { Ratio of outstanding principal balance of assets sold and securitized with servicing } \\
\text { retained or with recourse or other seller-provided credit enhancements to assets }\end{array}$ & Call report \\
\hline Asset sales & $\begin{array}{l}\text { Ratio of assets sold with recourse or other seller-provided credit enhancements } \\
\text { and not securitized to assets }\end{array}$ & Call report \\
\hline Loan loss provisioning & Ratio of loan loss provisioning to loans & Call report \\
\hline Net charge-offs & Ratio of loan charge-offs minus recoveries to loans & Call report \\
\hline Share of real estate loans & Share of real estate loans in total loans & Call report \\
\hline
\end{tabular}


Table 1. Summary Statistics for 2008, Quarterly Data

\begin{tabular}{|c|c|c|c|c|c|}
\hline & Mean & St. dev. & Minimum & Maximum & Number \\
\hline Tobin's $q$ & 1.0133 & 0.0550 & 0.8976 & 1.3280 & 1152 \\
\hline $\begin{array}{l}\text { Share of MBS held-to- } \\
\text { maturity, guaranteed }\end{array}$ & 0.0628 & 0.1844 & 0 & 1 & 1118 \\
\hline $\begin{array}{l}\text { Share of MBS held-to- } \\
\text { maturity, not guaranteed }\end{array}$ & 0.0957 & 0.2501 & 0 & 1 & 598 \\
\hline Loans & 0.7142 & 0.1170 & 0.0517 & 0.9593 & 1152 \\
\hline Real estate loans & 0.5360 & 0.1453 & 0 & 0.8880 & 1152 \\
\hline Securities & 0.1686 & 0.0987 & 0 & 0.7702 & 1152 \\
\hline MBS & 0.0959 & 0.0777 & 0 & 0.5758 & 1152 \\
\hline MBS, held & 0.0083 & 0.0319 & 0 & 0.3594 & 1152 \\
\hline MBS, for sale & 0.0876 & 0.0699 & 0 & 0.4456 & 1152 \\
\hline MBS, held, guaranteed & 0.0071 & 0.0289 & 0 & 0.3577 & 1152 \\
\hline MBS, held, not guaranteed & 0.0012 & 0.0113 & 0 & 0.2006 & 1152 \\
\hline MBS, for sale, guaranteed & 0.0798 & 0.0642 & 0 & 0.4009 & 1152 \\
\hline MBS, for sale, not guaranteed & 0.0078 & 0.0174 & 0 & 0.1592 & 1152 \\
\hline Large bank & 0.4983 & 0.5002 & 0 & 1 & 1152 \\
\hline HPI & 3.9383 & 1.2065 & 2.0982 & 6.9824 & 1132 \\
\hline Low valuation & 0.4991 & 0.5002 & 0 & 1 & 1152 \\
\hline Trading & 0.0053 & 0.0253 & 0 & 0.2996 & 1152 \\
\hline Deposits & 0.7194 & 0.1088 & 0.1227 & 0.9028 & 1152 \\
\hline Deposits, large, short-term & 0.0250 & 0.0317 & 0 & 0.3580 & 1152 \\
\hline Commercial paper & 0.0010 & 0.0052 & 0 & 0.0628 & 1152 \\
\hline Tier 1 & 0.8634 & 0.0816 & 0.5000 & 1 & 1152 \\
\hline Credit derivatives, positive & 0.0147 & 0.1571 & 0 & 2.9420 & 1152 \\
\hline Credit derivatives, negative & 0.0142 & 0.1515 & 0 & 2.8203 & 1152 \\
\hline Securitized & 0.0145 & 0.0756 & 0 & 0.7292 & 1152 \\
\hline Asset sales & 0.0032 & 0.0130 & 0 & 0.1440 & 1152 \\
\hline Loan loss provisioning & 0.0077 & 0.0107 & -0.0004 & 0.1435 & 1152 \\
\hline Net charge-offs & 0.0050 & 0.0077 & -0.0009 & 0.0906 & 1152 \\
\hline Share of real estate loans & 0.7429 & 0.1480 & 0 & 1 & 1152 \\
\hline
\end{tabular}

Note: See the appendix for variable definitions and data sources. 
Table 2. Tobin's $q$ and Real Estate Related Assets in 2008

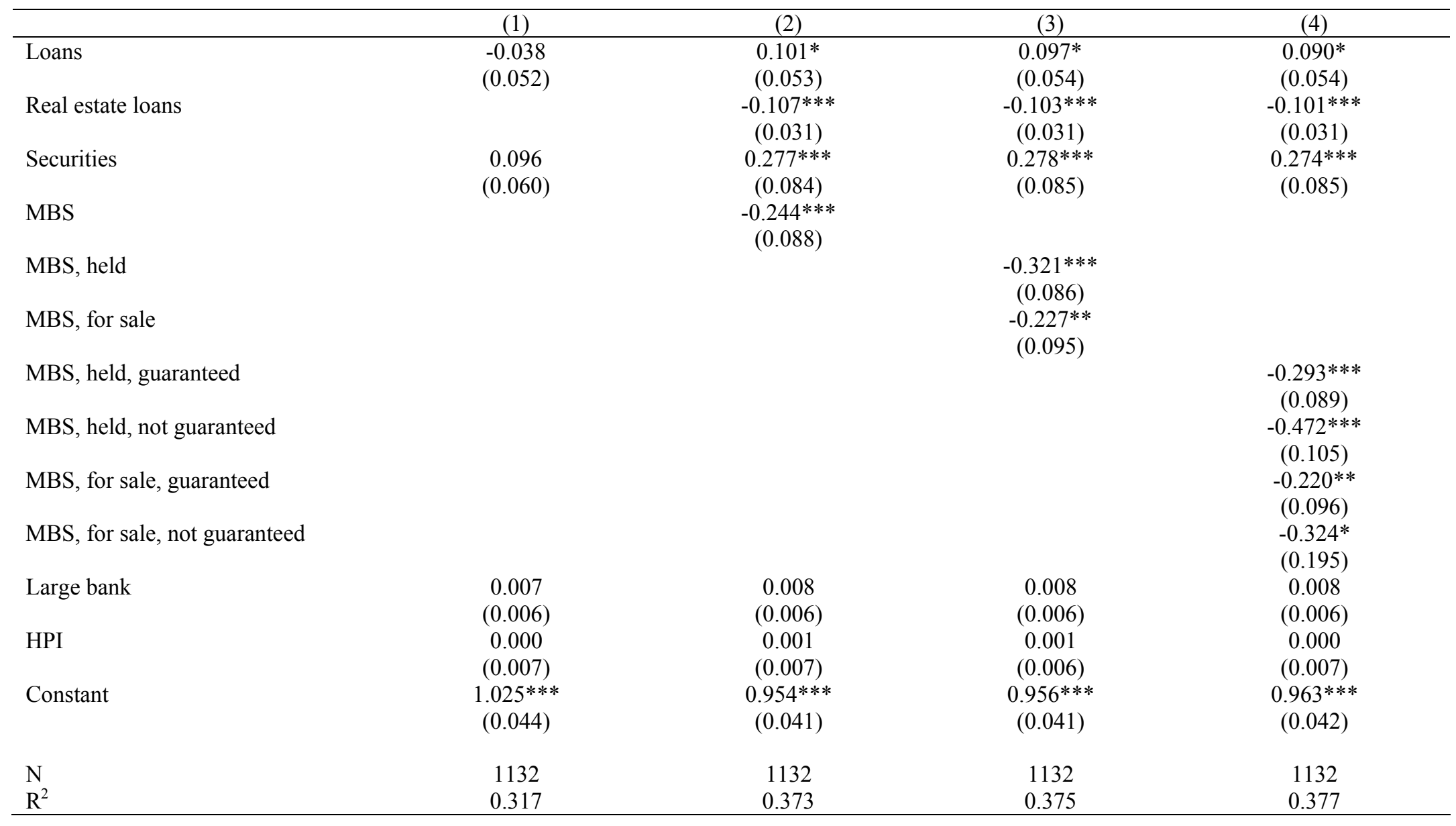

The dependent variable is Tobin's $q$. See the appendix for variable definitions and data sources. Regressions include state fixed effects and quarterly period fixed effects (not reported). Data are based on quarterly observations during the year 2008. Standard errors are corrected for clustering at the bank level. *,**, and *** denote significance at the $10 \%, 5 \%$ and $1 \%$ levels, respectively. 
Table 3. Tobin's $q$ and Real Estate Related Assets in 2001-2007

\begin{tabular}{|c|c|c|c|c|c|c|c|}
\hline & $\begin{array}{c}2001 \\
(1) \\
\end{array}$ & $\begin{array}{c}2002 \\
(2) \\
\end{array}$ & $\begin{array}{c}2003 \\
(3) \\
\end{array}$ & $\begin{array}{c}2004 \\
(4)\end{array}$ & $\begin{array}{c}2005 \\
(5) \\
\end{array}$ & $\begin{array}{c}2006 \\
(6) \\
\end{array}$ & $\begin{array}{c}2007 \\
(7) \\
\end{array}$ \\
\hline Loans & $\begin{array}{c}0.197 \\
(0.136)\end{array}$ & $\begin{array}{c}0.127 * * * \\
(0.047)\end{array}$ & $\begin{array}{c}0.063 \\
(0.053)\end{array}$ & $\begin{array}{c}0.114^{* *} \\
(0.050)\end{array}$ & $\begin{array}{c}0.166^{* * * *} \\
(0.052)\end{array}$ & $\begin{array}{l}0.124^{*} \\
(0.065)\end{array}$ & $\begin{array}{c}0.085 \\
(0.064)\end{array}$ \\
\hline Real estate loans & $\begin{array}{c}-0.070 \\
(0.048)\end{array}$ & $\begin{array}{l}-0.005 \\
(0.035)\end{array}$ & $\begin{array}{c}0.016 \\
(0.034)\end{array}$ & $\begin{array}{c}-0.041 \\
(0.034)\end{array}$ & $\begin{array}{c}-0.074 * * \\
(0.030)\end{array}$ & $\begin{array}{c}-0.081 * * \\
(0.033)\end{array}$ & $\begin{array}{c}-0.101 * * * \\
(0.033)\end{array}$ \\
\hline Securities & $\begin{array}{c}0.131 \\
(0.121)\end{array}$ & $\begin{array}{c}0.076 \\
(0.054)\end{array}$ & $\begin{array}{c}0.063 \\
(0.055)\end{array}$ & $\begin{array}{c}0.069 \\
(0.051)\end{array}$ & $\begin{array}{l}0.092^{*} \\
(0.051)\end{array}$ & $\begin{array}{c}0.077 \\
(0.065)\end{array}$ & $\begin{array}{c}0.077 \\
(0.068)\end{array}$ \\
\hline MBS, held & $\begin{array}{l}-0.041 \\
(0.087)\end{array}$ & $\begin{array}{c}0.066 \\
(0.080)\end{array}$ & $\begin{array}{c}0.017 \\
(0.085)\end{array}$ & $\begin{array}{c}-0.034 \\
(0.063)\end{array}$ & $\begin{array}{c}-0.069 \\
(0.058)\end{array}$ & $\begin{array}{l}-0.049 \\
(0.069)\end{array}$ & $\begin{array}{l}-0.086 \\
(0.080)\end{array}$ \\
\hline MBS, for sale & $\begin{array}{c}-0.088 \\
(0.072)\end{array}$ & $\begin{array}{c}-0.032 \\
(0.057)\end{array}$ & $\begin{array}{c}-0.041 \\
(0.048)\end{array}$ & $\begin{array}{c}0.001 \\
(0.049)\end{array}$ & $\begin{array}{l}-0.016 \\
(0.050)\end{array}$ & $\begin{array}{c}-0.037 \\
(0.057)\end{array}$ & $\begin{array}{l}-0.089 \\
(0.068)\end{array}$ \\
\hline Large bank & $\begin{array}{c}0.063 * * * \\
(0.009)\end{array}$ & $\begin{array}{c}0.057 * * * \\
(0.007)\end{array}$ & $\begin{array}{c}0.034 * * * \\
(0.006)\end{array}$ & $\begin{array}{c}0.034 * * * \\
(0.006)\end{array}$ & $\begin{array}{c}0.020 * * * \\
(0.005)\end{array}$ & $\begin{array}{c}0.019 * * * \\
(0.006)\end{array}$ & $\begin{array}{l}0.009 * \\
(0.005)\end{array}$ \\
\hline HPI & $\begin{array}{c}0.022 \\
(0.014)\end{array}$ & $\begin{array}{c}-0.024 \\
(0.023)\end{array}$ & $\begin{array}{c}0.008 \\
(0.014)\end{array}$ & $\begin{array}{l}0.013^{*} \\
(0.007)\end{array}$ & $\begin{array}{c}0.006 \\
(0.008)\end{array}$ & $\begin{array}{c}0.005 \\
(0.017)\end{array}$ & $\begin{array}{c}0.035^{* * *} * \\
(0.010)\end{array}$ \\
\hline Constant & $\begin{array}{c}0.832 * * * \\
(0.116)\end{array}$ & $\begin{array}{c}0.972 * * * \\
(0.057)\end{array}$ & $\begin{array}{c}0.990 * * * \\
(0.052)\end{array}$ & $\begin{array}{c}0.978 * * * \\
(0.039)\end{array}$ & $\begin{array}{c}0.962 * * * \\
(0.040)\end{array}$ & $\begin{array}{c}1.001 * * * \\
(0.067)\end{array}$ & $\begin{array}{c}0.947 * * * \\
(0.054)\end{array}$ \\
\hline $\begin{array}{l}\mathrm{N} \\
\mathrm{R}^{2}\end{array}$ & $\begin{array}{c}286 \\
0.371\end{array}$ & $\begin{array}{l}1186 \\
0.337 \\
\end{array}$ & $\begin{array}{c}1250 \\
0.257\end{array}$ & $\begin{array}{r}1274 \\
0.311 \\
\end{array}$ & $\begin{array}{c}1297 \\
0.327\end{array}$ & $\begin{array}{l}1169 \\
0.316 \\
\end{array}$ & $\begin{array}{c}1172 \\
0.354\end{array}$ \\
\hline
\end{tabular}

The dependent variable is Tobin's $q$. See the Appendix for variable definitions and data sources. Regressions include state fixed effects and quarterly period fixed effects (not reported). Data are based on quarterly observations over the period 2001-2007. Standard errors are corrected for clustering at the bank level. *, $* *$, and $* * *$ denote significance at the $10 \%, 5 \%$ and $1 \%$ levels, respectively. 
Table 4. Tobin's q, Real Estate Related Assets, and Asset Size

\begin{tabular}{|c|c|c|c|}
\hline & $\begin{array}{c}\text { Small banks } \\
\text { (1) }\end{array}$ & $\begin{array}{l}\text { Large banks } \\
\text { (2) }\end{array}$ & $\begin{array}{l}\text { Interactions with Large bank } \\
\text { (3) }\end{array}$ \\
\hline Loans & $\begin{array}{c}0.233^{* * *} \\
(0.078)\end{array}$ & $\begin{array}{c}0.117 \\
(0.071)\end{array}$ & $\begin{array}{c}0.146^{* *} \\
(0.058)\end{array}$ \\
\hline Real estate loans & $\begin{array}{l}-0.053 \\
(0.037)\end{array}$ & $\begin{array}{c}-0.151^{* * *} \\
(0.045)\end{array}$ & $\begin{array}{l}-0.035 \\
(0.036)\end{array}$ \\
\hline Real estate loans * Large bank & & & $\begin{array}{l}-0.127 * * \\
(0.053)\end{array}$ \\
\hline Securities & $\begin{array}{c}0.375 * * * \\
(0.077)\end{array}$ & $\begin{array}{c}0.394 * * * \\
(0.133)\end{array}$ & $\begin{array}{c}0.346 * * * \\
(0.091)\end{array}$ \\
\hline MBS, held & $\begin{array}{c}-0.409 * * * \\
(0.107)\end{array}$ & $\begin{array}{l}-0.274^{*} \\
(0.151)\end{array}$ & $\begin{array}{c}-0.433^{* * *} \\
(0.104)\end{array}$ \\
\hline MBS, held * Large bank & & & $\begin{array}{c}0.210 \\
(0.135)\end{array}$ \\
\hline MBS, for sale & $\begin{array}{c}-0.222 * * \\
(0.095)\end{array}$ & $\begin{array}{l}-0.270^{*} \\
(0.143)\end{array}$ & $\begin{array}{c}-0.280 * * * \\
(0.100)\end{array}$ \\
\hline MBS, for sale * Large bank & & & $\begin{array}{c}0.070 \\
(0.096)\end{array}$ \\
\hline Large bank & & & $\begin{array}{l}0.071^{*} \\
(0.037)\end{array}$ \\
\hline HPI & $\begin{array}{l}-0.001 \\
(0.010)\end{array}$ & $\begin{array}{c}0.006 \\
(0.008)\end{array}$ & $\begin{array}{c}0.003 \\
(0.006)\end{array}$ \\
\hline Constant & $\begin{array}{c}0.832 * * * \\
(0.060)\end{array}$ & $\begin{array}{c}0.972 * * * \\
(0.051)\end{array}$ & $\begin{array}{c}0.874 * * * \\
(0.052)\end{array}$ \\
\hline $\begin{array}{l}\mathrm{N} \\
\mathrm{R}^{2}\end{array}$ & $\begin{array}{c}578 \\
0.408\end{array}$ & $\begin{array}{c}554 \\
0.495\end{array}$ & $\begin{array}{l}1132 \\
0.403\end{array}$ \\
\hline
\end{tabular}

The dependent variable is Tobin's $q$. See the Appendix for variable definitions and data sources. Subsample in Column (1) consists of banks with below-median total assets in a given quarter. Subsample in Column (2) consists of banks with above-median total assets in a given quarter. Regressions include state fixed effects and quarterly period fixed effects (not reported). Data are based on quarterly observations during the year 2008. Standard errors are corrected for clustering at the bank level. *,**, and ${ }^{* * *}$ denote significance at the $10 \%, 5 \%$ and $1 \%$ levels, respectively. 
Table 5. Tobin's $q$ and Additional Balance Sheet and Off-Balance Sheet Items

\begin{tabular}{|c|c|c|c|c|}
\hline & $(1)$ & (2) & (3) & (4) \\
\hline Loans & $\begin{array}{c}0.035 \\
(0.080)\end{array}$ & $\begin{array}{c}0.018 \\
(0.084)\end{array}$ & $\begin{array}{c}0.019 \\
(0.079)\end{array}$ & $\begin{array}{c}0.018 \\
(0.078)\end{array}$ \\
\hline Real estate Loans & $\begin{array}{c}-0.102 * * * \\
(0.031)\end{array}$ & $\begin{array}{c}-0.092 * * * \\
(0.031)\end{array}$ & $\begin{array}{c}-0.100 * * * \\
(0.031)\end{array}$ & $\begin{array}{c}-0.101 * * * \\
(0.031)\end{array}$ \\
\hline Securities & $\begin{array}{l}0.206^{*} \\
(0.114)\end{array}$ & $\begin{array}{l}0.191 * \\
(0.115)\end{array}$ & $\begin{array}{c}0.141 \\
(0.117)\end{array}$ & $\begin{array}{c}0.135 \\
(0.116)\end{array}$ \\
\hline MBS, held, guaranteed & $\begin{array}{c}-0.286^{* * * *} \\
(0.089)\end{array}$ & $\begin{array}{c}-0.270 * * * \\
(0.090)\end{array}$ & $\begin{array}{c}-0.260 * * * \\
(0.089)\end{array}$ & $\begin{array}{c}-0.257 * * * \\
(0.088)\end{array}$ \\
\hline MBS, held, not guaranteed & $\begin{array}{c}-0.448 * * * \\
(0.109)\end{array}$ & $\begin{array}{c}-0.420 * * * \\
(0.107)\end{array}$ & $\begin{array}{c}-0.389 * * * \\
(0.106)\end{array}$ & $\begin{array}{c}-0.387 * * * \\
(0.110)\end{array}$ \\
\hline MBS, for sale, guaranteed & $\begin{array}{c}-0.207 * * \\
(0.098)\end{array}$ & $\begin{array}{c}-0.194 * * \\
(0.096)\end{array}$ & $\begin{array}{c}-0.174 * \\
(0.095)\end{array}$ & $\begin{array}{c}-0.171^{*} \\
(0.096)\end{array}$ \\
\hline MBS, for sale, not guaranteed & $\begin{array}{c}-0.329 * \\
(0.194)\end{array}$ & $\begin{array}{l}-0.286 \\
(0.207)\end{array}$ & $\begin{array}{l}-0.187 \\
(0.211)\end{array}$ & $\begin{array}{l}-0.182 \\
(0.213)\end{array}$ \\
\hline Trading & $\begin{array}{l}-0.190 \\
(0.135)\end{array}$ & $\begin{array}{l}-0.168 \\
(0.166)\end{array}$ & $\begin{array}{l}-0.142 \\
(0.157)\end{array}$ & $\begin{array}{l}-0.039 \\
(0.181)\end{array}$ \\
\hline Deposits & & $\begin{array}{c}0.044 \\
(0.052)\end{array}$ & $\begin{array}{c}0.032 \\
(0.051)\end{array}$ & $\begin{array}{c}0.029 \\
(0.053)\end{array}$ \\
\hline Deposits, large, short-term & & $\begin{array}{c}-0.157 * * \\
(0.079)\end{array}$ & $\begin{array}{c}-0.161 * * \\
(0.078)\end{array}$ & $\begin{array}{c}-0.167 * * \\
(0.079)\end{array}$ \\
\hline Commercial paper & & $\begin{array}{c}0.506 \\
(0.324)\end{array}$ & $\begin{array}{l}0.604 * \\
(0.317)\end{array}$ & $\begin{array}{c}0.675 * * \\
(0.337)\end{array}$ \\
\hline Tier 1 & & & $\begin{array}{c}0.104 * * * \\
(0.033)\end{array}$ & $\begin{array}{c}0.101 * * * \\
(0.034)\end{array}$ \\
\hline Credit derivatives, positive & & & & $\begin{array}{l}-0.082 \\
(0.258)\end{array}$ \\
\hline Credit derivatives, negative & & & & $\begin{array}{c}0.064 \\
(0.260)\end{array}$ \\
\hline Securitized & & & & $\begin{array}{l}-0.019 \\
(0.034)\end{array}$ \\
\hline Asset sales & & & & $\begin{array}{c}0.003 \\
(0.007)\end{array}$ \\
\hline Large bank & $\begin{array}{c}0.008 \\
(0.006)\end{array}$ & $\begin{array}{c}0.009 \\
(0.007)\end{array}$ & $\begin{array}{l}0.012^{*} \\
(0.006)\end{array}$ & $\begin{array}{c}0.906 * * * \\
(0.078)\end{array}$ \\
\hline HPI & $\begin{array}{c}0.001 \\
(0.007)\end{array}$ & $\begin{array}{c}0.003 \\
(0.007)\end{array}$ & $\begin{array}{c}0.003 \\
(0.007)\end{array}$ & $\begin{array}{c}0.018 \\
(0.078)\end{array}$ \\
\hline Constant & $\begin{array}{c}1.008^{* * * *} \\
(0.064)\end{array}$ & $\begin{array}{c}0.976 * * * \\
(0.084)\end{array}$ & $\begin{array}{c}0.898 * * * \\
(0.077)\end{array}$ & $\begin{array}{c}-0.101 * * * \\
(0.031)\end{array}$ \\
\hline $\begin{array}{l}\mathrm{N} \\
\mathrm{R}^{2}\end{array}$ & $\begin{array}{l}1132 \\
0.380\end{array}$ & $\begin{array}{l}1132 \\
0.389 \\
\end{array}$ & $\begin{array}{l}1132 \\
0.401 \\
\end{array}$ & $\begin{array}{l}1132 \\
0.403 \\
\end{array}$ \\
\hline
\end{tabular}

The dependent variable is Tobin's $q$. See the Appendix for variable definitions and data sources. Regressions include state fixed effects and quarterly period fixed effects (not reported). Data are based on quarterly observations during the year 2008. Standard errors are corrected for clustering at the bank level. *, **, and $* * *$ denote significance at the $10 \%, 5 \%$ and $1 \%$ levels, respectively. 
Table 6. Event Study of New FASB Rules on Fair Value Accounting of Illiquid Assets (FAS 157), Announced on October 10, 2008

Panel A: Event window is October 8, 2008 until October 12, 2008

\begin{tabular}{|c|c|c|c|c|c|}
\hline & $\begin{array}{c}(1) \\
\text { All firms } \\
\end{array}$ & $\begin{array}{c}(2) \\
\text { Large } \\
\end{array}$ & $\begin{array}{c}(3) \\
\text { Small } \\
\end{array}$ & $\begin{array}{c}\text { (4) } \\
\text { Low share of MBS }\end{array}$ & $\begin{array}{c}(5) \\
\text { High share of MBS } \\
\end{array}$ \\
\hline CAR & $\begin{array}{l}0.0128^{*} \\
(0.0070)\end{array}$ & $\begin{array}{c}0.0260 * * * \\
(0.0092)\end{array}$ & $\begin{array}{l}-0.0005 \\
(0.0105)\end{array}$ & $\begin{array}{c}0.0116 \\
(0.0111)\end{array}$ & $\begin{array}{c}0.0140 \\
(0.0087)\end{array}$ \\
\hline Observations & 270 & 136 & 134 & 134 & 136 \\
\hline \multicolumn{6}{|c|}{ Panel B: Event window is October 10, 2008} \\
\hline & $\begin{array}{c}(1) \\
\text { All firms } \\
\end{array}$ & $\begin{array}{c}(2) \\
\text { Large }\end{array}$ & $\begin{array}{c}(3) \\
\text { Small } \\
\end{array}$ & $\begin{array}{c}\text { (4) } \\
\text { Low share of MBS }\end{array}$ & $\begin{array}{c}(5) \\
\text { High share of MBS } \\
\end{array}$ \\
\hline CAR & $\begin{array}{c}0.0761 * * * \\
(0.0074)\end{array}$ & $\begin{array}{c}0.1290 * * * \\
(0.0079)\end{array}$ & $\begin{array}{l}0.0225 * * \\
(0.0107)\end{array}$ & $\begin{array}{l}0.0616 * * * \\
(0.0113)\end{array}$ & $\begin{array}{c}0.0903 * * * \\
(0.0094)\end{array}$ \\
\hline Observations & 270 & 136 & 134 & 134 & 136 \\
\hline
\end{tabular}

This table reports average cumulative abnormal returns for different subsamples of firms. Cumulative abnormal returns are based on a market model with estimation window of [t-250, $\mathrm{t}-30]$, where $\mathrm{t}$ denotes October 10, 2008, and time is counted in trading days. Panel A reports results using an event window of ( $\mathrm{t}-3$, $\mathrm{t}+2$ ], where $\mathrm{t}$ denotes October 10,2008, and time is counted in trading days, while Panel B reports results using an event window of ( $\mathrm{t}-1$, $\mathrm{t}]$. Observations from firms with more than 100 zero returns over the estimation window or a zero return on the event date are excluded from the sample. Large (small) denotes firms with total assets above (below) the quarterly sample median. High (Low) share of MBS denotes firms with mortgage-backed securities as a fraction of total assets above (below) the quarterly sample median. Standard errors of the average cumulative abnormal returns are reported in parentheses. $* * * * *$, and * denote significance at the $1 \%, 5 \%$, and $10 \%$ level, respectively. 
Table 7. Event Study of FASB Amendments to Fair Value Accounting of Hard-to-Value Assets, Announced on April 9, 2009.

Panel A: Event window is April 7, 2009 until April 11, 2009

\begin{tabular}{|c|c|c|c|c|c|}
\hline & $\begin{array}{c}(1) \\
\text { All firms } \\
\end{array}$ & $\begin{array}{c}(2) \\
\text { Large } \\
\end{array}$ & $\begin{array}{c}(3) \\
\text { Small } \\
\end{array}$ & $\begin{array}{c}\text { (4) } \\
\text { Low share of MBS } \\
\end{array}$ & $\begin{array}{c}\text { (5) } \\
\text { High share of MBS } \\
\end{array}$ \\
\hline CAR & $\begin{array}{c}0.0643 * * * \\
(0.0066)\end{array}$ & $\begin{array}{c}0.0899 * * * \\
(0.0092)\end{array}$ & $\begin{array}{c}0.0390 * * * \\
(0.0090)\end{array}$ & $\begin{array}{c}0.0632 * * * \\
(0.0094)\end{array}$ & $\begin{array}{c}0.0654 * * * \\
(0.0093)\end{array}$ \\
\hline Observations & 255 & 127 & 128 & 127 & 128 \\
\hline \multicolumn{6}{|c|}{ Panel B: Event window is April 9, 2009} \\
\hline & $\begin{array}{c}(1) \\
\text { All firms } \\
\end{array}$ & $\begin{array}{c}(2) \\
\text { Large }\end{array}$ & $\begin{array}{c}(3) \\
\text { Small } \\
\end{array}$ & $\begin{array}{c}\text { (4) } \\
\text { Low share of MBS } \\
\end{array}$ & $\begin{array}{c}\text { (5) } \\
\text { High share of MBS } \\
\end{array}$ \\
\hline CAR & $\begin{array}{c}0.0499 * * * \\
(0.0043)\end{array}$ & $\begin{array}{c}0.0662 * * * \\
(0.0054)\end{array}$ & $\begin{array}{c}0.0337 * * * \\
(0.0063)\end{array}$ & $\begin{array}{c}0.0497 * * * \\
(0.0067)\end{array}$ & $\begin{array}{c}0.0501 * * * \\
(0.0053)\end{array}$ \\
\hline Observations & 255 & 127 & 128 & 127 & 128 \\
\hline
\end{tabular}

This table reports average cumulative abnormal returns for different subsamples of firms. Cumulative abnormal returns are based on a market model with estimation window of [t-250, t-30], where $t$ denotes October 10, 2008, and time is counted in trading days. Panel A reports results using an event window of ( $\mathrm{t}-3$, $\mathrm{t}+2$ ], where $\mathrm{t}$ denotes April 9, 2009, and time is counted in trading days, while Panel B reports results using an event window of (t-1, t]. Observations from firms with more than 100 zero returns over the estimation window or a zero return on the event date are excluded from the sample. Large (small) denotes firms with total assets above (below) the quarterly sample median. High (Low) share of MBS denotes firms with mortgage-backed securities as a fraction of total assets above (below) the quarterly sample median. Standard errors of the average cumulative abnormal returns are reported in parentheses. ***,**, and $*$ denote significance at the $1 \%, 5 \%$, and $10 \%$ level, respectively. 
Table 8. Loan Loss Provisions and Net Loan Charge-offs in 2008

\begin{tabular}{|c|c|c|c|c|c|c|}
\hline & \multicolumn{3}{|c|}{ Loan loss provisioning } & \multicolumn{3}{|c|}{ Net loan charge-offs } \\
\hline & All banks & Low valuation & High valuation & All banks & Low valuation & High valuation \\
\hline & $(1)$ & $(2)$ & (3) & (4) & (5) & (6) \\
\hline \multirow{2}{*}{ Share of real estate loans } & 0.004 & 0.000 & 0.000 & 0.003 & -0.001 & 0.000 \\
\hline & $(0.005)$ & $(0.008)$ & $(0.002)$ & $(0.003)$ & $(0.005)$ & $(0.002)$ \\
\hline \multirow[t]{2}{*}{ MBS } & $-0.015 * *$ & $-0.024 *$ & -0.002 & -0.008 & -0.010 & -0.000 \\
\hline & $(0.007)$ & $(0.013)$ & $(0.005)$ & $(0.005)$ & $(0.009)$ & $(0.004)$ \\
\hline \multirow[t]{2}{*}{ Large bank } & $0.004 * * *$ & $0.008 * * *$ & $0.001 *$ & $0.003 * * *$ & $0.005 * * *$ & 0.001 \\
\hline & $(0.001)$ & $(0.002)$ & $(0.001)$ & $(0.001)$ & $(0.001)$ & $(0.000)$ \\
\hline \multirow[t]{2}{*}{ HPI } & $-0.005 * *$ & -0.001 & $-0.009 * * *$ & $-0.005 * *$ & -0.003 & $-0.006 * *$ \\
\hline & $(0.002)$ & $(0.003)$ & $(0.003)$ & $(0.002)$ & $(0.003)$ & $(0.003)$ \\
\hline \multirow[t]{2}{*}{ Constant } & $0.013^{*}$ & 0.000 & $0.030 * * *$ & $0.012 *$ & 0.008 & $0.019 * * *$ \\
\hline & $(0.008)$ & $(0.012)$ & $(0.007)$ & $(0.006)$ & $(0.010)$ & $(0.007)$ \\
\hline $\mathrm{N}$ & 1132 & 562 & 570 & 1132 & 562 & 570 \\
\hline $\mathrm{R}^{2}$ & 0.344 & 0.440 & 0.413 & 0.310 & 0.421 & 0.305 \\
\hline
\end{tabular}

The dependent variable is the ratio of loan loss provisioning to loans in Columns (1) to (3) and the ratio of loan charge-offs minus recoveries to loans in Columns (4) to (6). See the Appendix for variable definitions and data sources. Subsamples in Columns (2) and (5) consist of banks with below-median Tobin's $q$ in a given quarter. Subsamples in Columns (3) and (6) consist of banks with above-median Tobin's Q in a given quarter. Regressions include state fixed effects and quarterly period fixed effects (not reported). Data are based on quarterly observations. Standard errors are corrected for clustering at the bank level. *, **, and $* * *$ denote significance at the $10 \%, 5 \%$ and $1 \%$ levels, respectively. 
Table 9. Share of Mortgage-Backed Securities that is Held-to-Maturity in 2008

\begin{tabular}{|c|c|c|c|c|c|c|}
\hline & $\begin{array}{c}\text { Guaranteed } \\
\text { (1) }\end{array}$ & $\begin{array}{c}\text { Not guaranteed } \\
\text { (2) }\end{array}$ & $\begin{array}{l}\text { Guaranteed } \\
\text { (3) }\end{array}$ & $\begin{array}{c}\text { Not guaranteed } \\
\text { (4) }\end{array}$ & $\begin{array}{l}\text { Guaranteed } \\
\text { (5) }\end{array}$ & $\begin{array}{c}\text { Not guaranteed } \\
\text { (6) }\end{array}$ \\
\hline \multirow[t]{2}{*}{ Loans } & 0.030 & $-0.913 * * *$ & 0.068 & $-0.855 * * *$ & 0.073 & $-0.914 * * *$ \\
\hline & $(0.268)$ & $(0.284)$ & $(0.274)$ & $(0.269)$ & $(0.273)$ & $(0.292)$ \\
\hline \multirow[t]{2}{*}{ Real estate loans } & 0.031 & $0.731 * * *$ & 0.015 & $0.701 * * *$ & -0.022 & $0.561 * *$ \\
\hline & $(0.208)$ & $(0.229)$ & $(0.207)$ & $(0.215)$ & $(0.218)$ & $(0.215)$ \\
\hline \multirow[t]{2}{*}{ Real estate loans * Low valuation } & & & & & 0.073 & 0.321 \\
\hline & & & & & $(0.155)$ & $(0.249)$ \\
\hline \multirow{2}{*}{ Securities, amortized cost } & 0.148 & -0.219 & 0.210 & -0.139 & 0.197 & -0.296 \\
\hline & $(0.244)$ & $(0.493)$ & $(0.253)$ & $(0.488)$ & $(0.245)$ & $(0.499)$ \\
\hline \multirow[t]{2}{*}{ MBS, amortized cost } & 0.354 & 1.048 & 0.332 & 1.036 & 0.303 & 0.649 \\
\hline & $(0.280)$ & $(0.685)$ & $(0.275)$ & $(0.680)$ & $(0.268)$ & $(0.695)$ \\
\hline \multirow{2}{*}{ MBS, amortized cost * Low valuation } & & & & & 0.098 & $1.196^{*}$ \\
\hline & & & & & $(0.363)$ & $(0.662)$ \\
\hline \multirow[t]{2}{*}{ Low valuation } & & & 0.029 & 0.028 & -0.020 & -0.271 \\
\hline & & & $(0.019)$ & $(0.029)$ & $(0.103)$ & $(0.173)$ \\
\hline \multirow[t]{2}{*}{ Large bank } & -0.019 & 0.060 & -0.016 & 0.063 & -0.016 & $0.066^{*}$ \\
\hline & $(0.027)$ & $(0.041)$ & $(0.026)$ & $(0.040)$ & $(0.026)$ & $(0.039)$ \\
\hline \multirow[t]{2}{*}{ HPI } & 0.017 & 0.022 & 0.017 & 0.021 & 0.016 & 0.024 \\
\hline & $(0.016)$ & $(0.034)$ & $(0.016)$ & $(0.034)$ & $(0.016)$ & $(0.032)$ \\
\hline \multirow[t]{2}{*}{ Constant } & -0.101 & -0.028 & -0.148 & -0.069 & -0.121 & 0.068 \\
\hline & $(0.132)$ & $(0.296)$ & $(0.145)$ & $(0.297)$ & $(0.144)$ & $(0.305)$ \\
\hline $\mathrm{N}$ & 1098 & 582 & 1098 & 582 & 1098 & 582 \\
\hline $\mathrm{R}^{2}$ & 0.237 & 0.434 & 0.241 & 0.436 & 0.242 & 0.451 \\
\hline
\end{tabular}

The dependent variable is the share of mortgage-backed securities that is held-to-maturity. Low valuation is a dummy variable that takes a value of one if the bank has a Tobin's $q$ less than one, and zero otherwise. See the Appendix for variable definitions and data sources. Regressions include state fixed effects and quarterly period fixed effects (not reported). Data are based on quarterly observations. Standard errors are corrected for clustering at the bank level. *, **, and *** denote significance at the $10 \%, 5 \%$ and $1 \%$ levels, respectively. 
Table 10. Share of Non-Guaranteed Mortgage-Backed Securities that is Held-to-Maturity in 2001-2007

\begin{tabular}{|c|c|c|c|c|c|c|c|}
\hline & $\begin{array}{c}2001 \\
(1) \\
\end{array}$ & $\begin{array}{c}2002 \\
(2)\end{array}$ & $\begin{array}{c}2003 \\
(3) \\
\end{array}$ & $\begin{array}{c}2004 \\
(4) \\
\end{array}$ & $\begin{array}{c}2005 \\
(5) \\
\end{array}$ & $\begin{array}{c}2006 \\
(6)\end{array}$ & $\begin{array}{c}2007 \\
(7) \\
\end{array}$ \\
\hline Loans & $\begin{array}{c}0.116 \\
(0.412)\end{array}$ & $\begin{array}{c}0.293 \\
(0.363)\end{array}$ & $\begin{array}{c}0.029 \\
(0.404)\end{array}$ & $\begin{array}{c}-0.169 \\
(0.234)\end{array}$ & $\begin{array}{c}-0.641 * * \\
(0.282)\end{array}$ & $\begin{array}{c}-0.564 * * \\
(0.281)\end{array}$ & $\begin{array}{c}-0.619^{* *} \\
(0.309)\end{array}$ \\
\hline Real estate loans & $\begin{array}{c}0.137 \\
(0.320)\end{array}$ & $\begin{array}{c}0.037 \\
(0.286)\end{array}$ & $\begin{array}{c}0.138 \\
(0.316)\end{array}$ & $\begin{array}{c}0.346 \\
(0.212)\end{array}$ & $\begin{array}{c}0.533 * * \\
(0.227)\end{array}$ & $\begin{array}{c}0.424 * * \\
(0.206)\end{array}$ & $\begin{array}{c}0.475^{* *} \\
(0.213)\end{array}$ \\
\hline Securities, amortized & $\begin{array}{c}1.071 * * \\
(0.508)\end{array}$ & $\begin{array}{c}1.367 * * * \\
(0.447)\end{array}$ & $\begin{array}{c}0.781 * * \\
(0.368)\end{array}$ & $\begin{array}{c}0.407 \\
(0.362)\end{array}$ & $\begin{array}{c}0.354 \\
(0.361)\end{array}$ & $\begin{array}{c}0.330 \\
(0.348)\end{array}$ & $\begin{array}{c}0.024 \\
(0.321)\end{array}$ \\
\hline MBS, amortized & $\begin{array}{c}-0.413 \\
(0.604)\end{array}$ & $\begin{array}{l}-0.801 \\
(0.516)\end{array}$ & $\begin{array}{c}-0.419 \\
(0.378)\end{array}$ & $\begin{array}{c}0.068 \\
(0.384)\end{array}$ & $\begin{array}{c}0.242 \\
(0.469)\end{array}$ & $\begin{array}{l}-0.090 \\
(0.574)\end{array}$ & $\begin{array}{c}0.342 \\
(0.683)\end{array}$ \\
\hline Low valuation & $\begin{array}{c}0.011 \\
(0.076)\end{array}$ & $\begin{array}{c}0.029 \\
(0.042)\end{array}$ & $\begin{array}{c}0.049 \\
(0.035)\end{array}$ & $\begin{array}{c}0.049 \\
(0.033)\end{array}$ & $\begin{array}{l}-0.022 \\
(0.037)\end{array}$ & $\begin{array}{l}-0.026 \\
(0.029)\end{array}$ & $\begin{array}{l}-0.015 \\
(0.035)\end{array}$ \\
\hline Large bank & $\begin{array}{l}-0.065 \\
(0.090)\end{array}$ & $\begin{array}{l}-0.066 \\
(0.063)\end{array}$ & $\begin{array}{c}-0.048 \\
(0.054)\end{array}$ & $\begin{array}{c}-0.018 \\
(0.048)\end{array}$ & $\begin{array}{c}0.019 \\
(0.047)\end{array}$ & $\begin{array}{c}0.061 \\
(0.046)\end{array}$ & $\begin{array}{c}0.049 \\
(0.043)\end{array}$ \\
\hline HPI & $\begin{array}{c}0.114 \\
(0.095)\end{array}$ & $\begin{array}{c}-0.048 \\
(0.142)\end{array}$ & $\begin{array}{c}0.043 \\
(0.115)\end{array}$ & $\begin{array}{c}-0.099^{*} \\
(0.058)\end{array}$ & $\begin{array}{c}0.016 \\
(0.048)\end{array}$ & $\begin{array}{c}0.003 \\
(0.074)\end{array}$ & $\begin{array}{c}0.005 \\
(0.026)\end{array}$ \\
\hline Constant & $\begin{array}{l}-0.574 \\
(0.380)\end{array}$ & $\begin{array}{l}-0.281 \\
(0.376)\end{array}$ & $\begin{array}{l}-0.428 \\
(0.304)\end{array}$ & $\begin{array}{c}0.460 \\
(0.364)\end{array}$ & $\begin{array}{c}0.065 \\
(0.179)\end{array}$ & $\begin{array}{c}0.238 \\
(0.216)\end{array}$ & $\begin{array}{c}0.047 \\
(0.243)\end{array}$ \\
\hline $\begin{array}{l}\mathrm{N} \\
\mathrm{R}^{2}\end{array}$ & $\begin{array}{c}126 \\
0.381\end{array}$ & $\begin{array}{c}522 \\
0.346\end{array}$ & $\begin{array}{c}516 \\
0.270\end{array}$ & $\begin{array}{c}507 \\
0.316\end{array}$ & $\begin{array}{c}581 \\
0.349\end{array}$ & $\begin{array}{c}572 \\
0.274\end{array}$ & $\begin{array}{c}556 \\
0.438\end{array}$ \\
\hline
\end{tabular}

The dependent variable is the share of mortgage-backed securities that is held-to-maturity. Low valuation is a dummy variable that takes a value of one if the bank has a Tobin's $q$ less than one, and zero otherwise. See the Appendix for variable definitions and data sources. Regressions include state fixed effects and quarterly period fixed effects (not reported). Data are based on quarterly observations. Standard errors are corrected for clustering at the bank level. *, **, and $* * *$ denote significance at the $10 \%, 5 \%$ and $1 \%$ levels, respectively. 
Figure 1 . Tobin's $q$ and Share of Zombie Banks

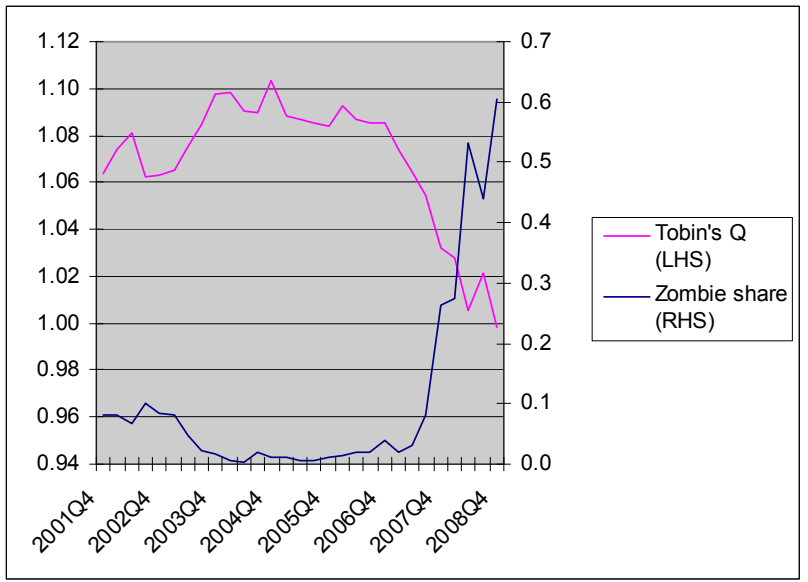

Tobin's q is the ratio of market value to book value of assets. Zombie share is the fraction of banks with Tobin's q less than 1. Quarterly data from Call reports and Datastream.

Figure 2. Real Estate Loans and Mortgage-backed Securities

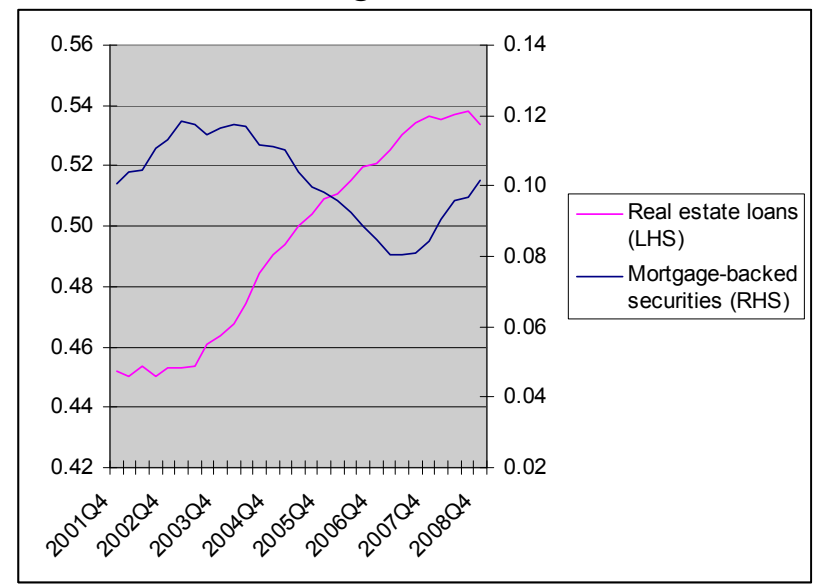

Real estate loans is the ratio of real estate loans to total assets. Mortgage-backed securities is the ratio of MBS to total assets. Securities are valued at amortized cost if held-to-maturity and at fair value if available-for-sale. Quarterly data from Call reports.

Figure 3. Share of Mortgage-backed Securities that is Held-to-Maturity

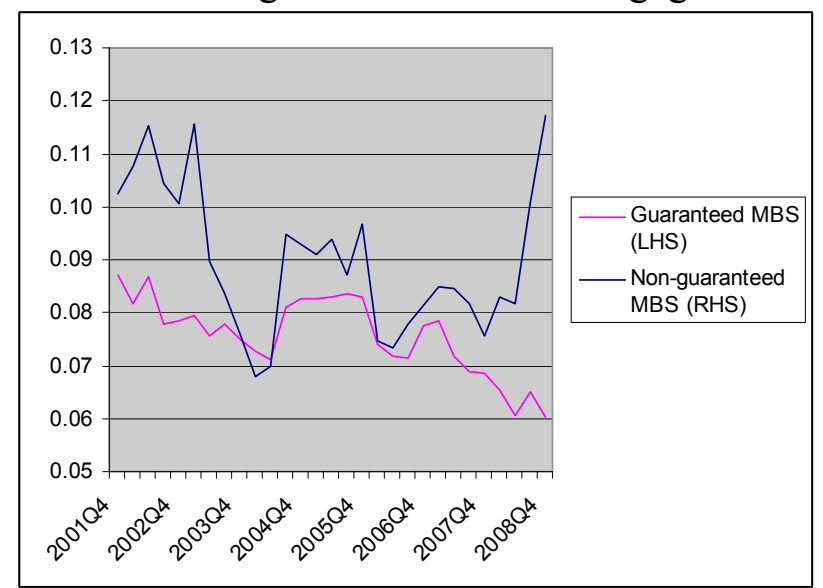

Guaranteed MBS is the fraction of guaranteed MBS that is held-to-maturity. Non-guaranteed MBS is the fraction of nonguaranteed MBS that is held-to-maturity. Quarterly data from Call reports. 
Figure 4. Fair Value of Mortgage-backed Securities Relative to Amortized Cost

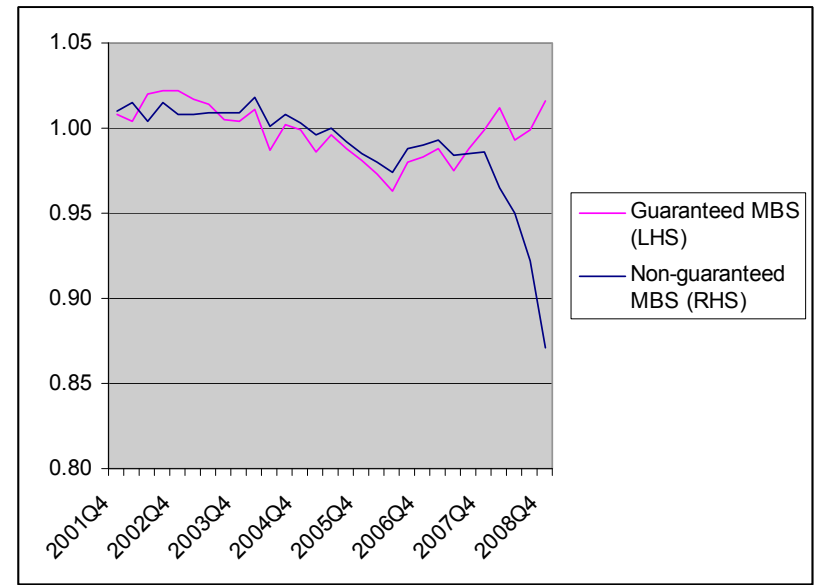

Guaranteed MBS is the fair value of guaranteed MBS to the amortized value of guaranteed MBS. Non-guaranteed MBS is the fair value of non-guaranteed MBS to the amortized value of non-guaranteed MBS. Quarterly data from Call reports.

\section{Figure 5. Capitalization and Composition of Bank Regulatory Capital}

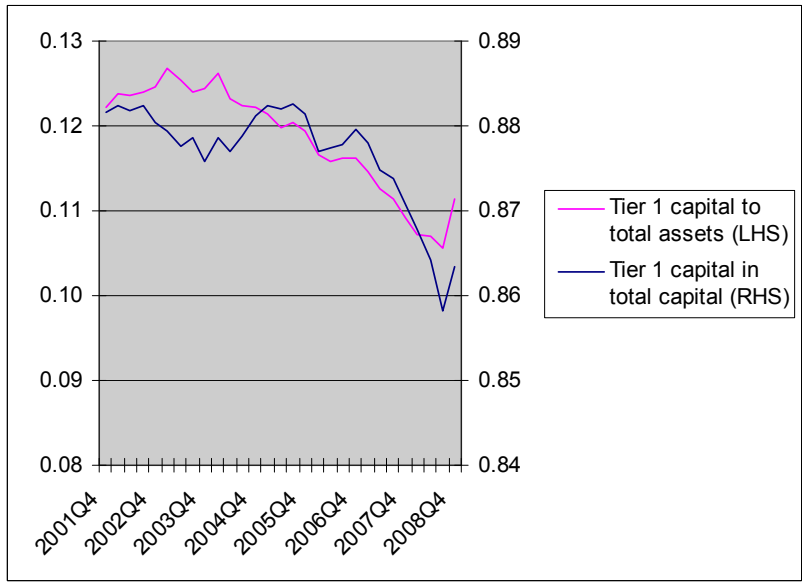

Tier 1 capital to total assets is the ratio of tier 1 capital to total risk-weighted assets. Tier 1 capital in total capital is the ratio of tier 1 capital to total regulatory capital. Quarterly data from Call reports. 